SB 483

. C564 


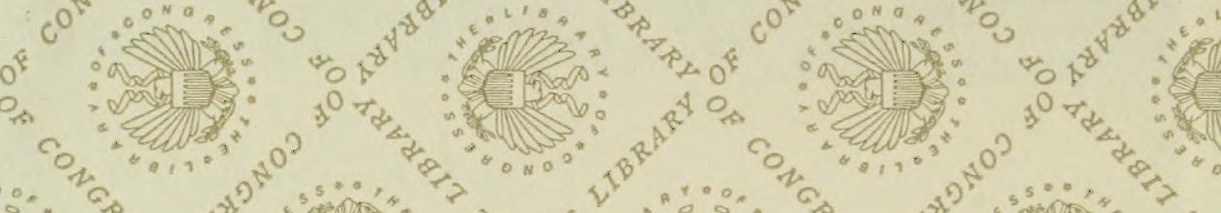

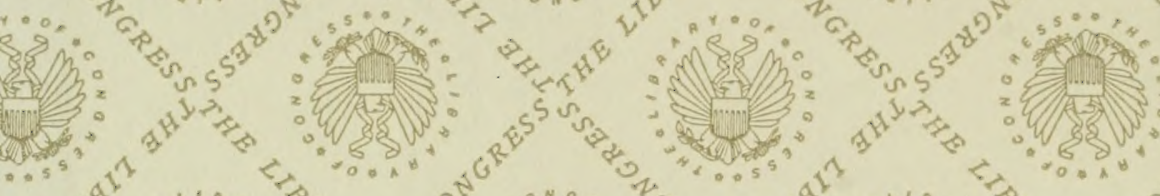
on

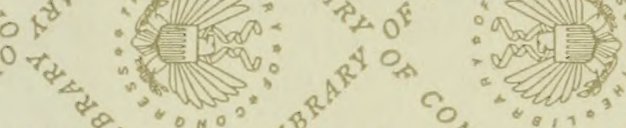

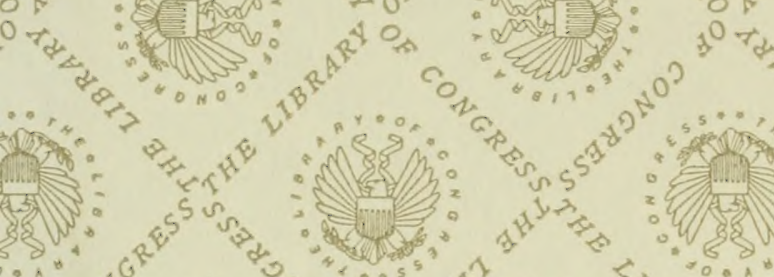

10.

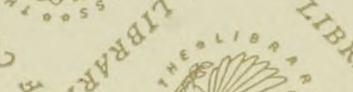

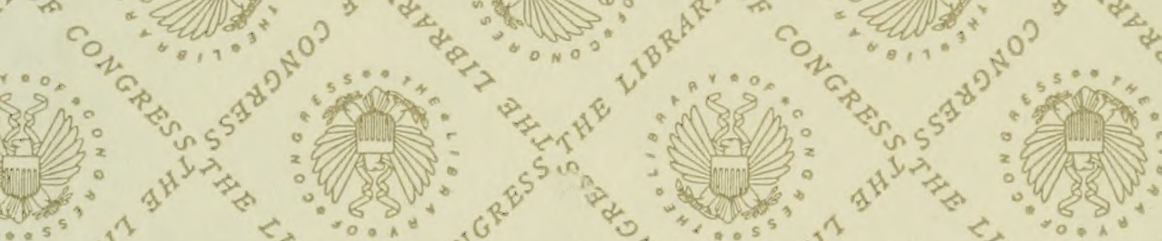

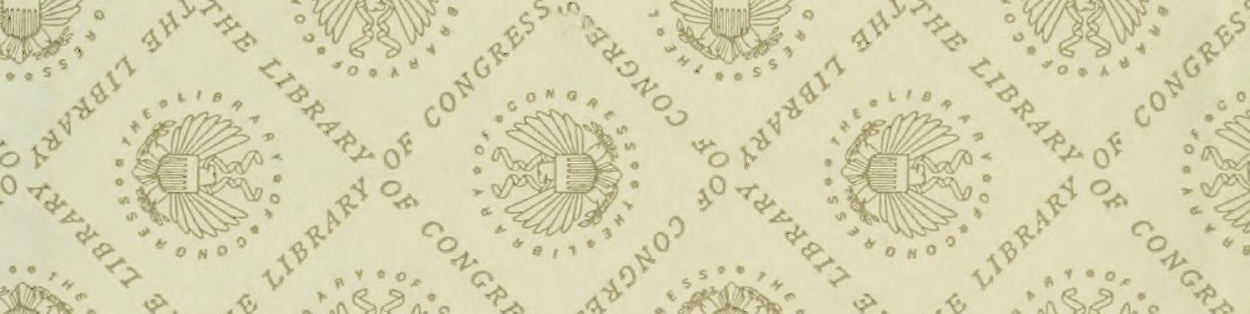
(2)

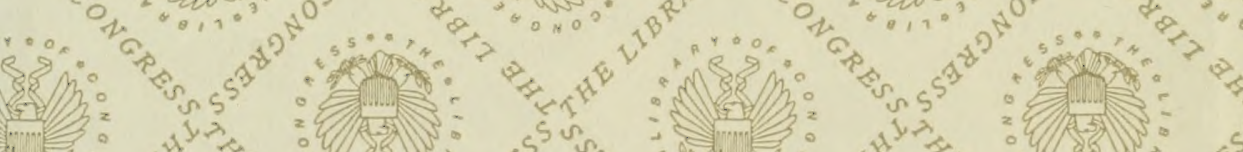

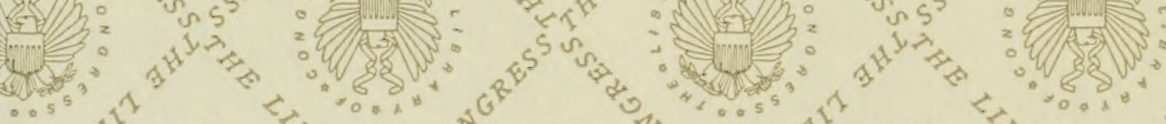

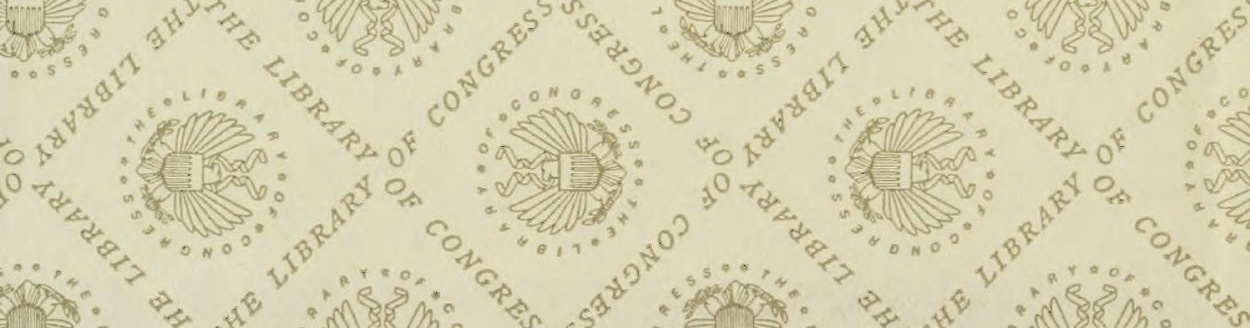

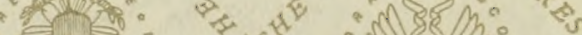




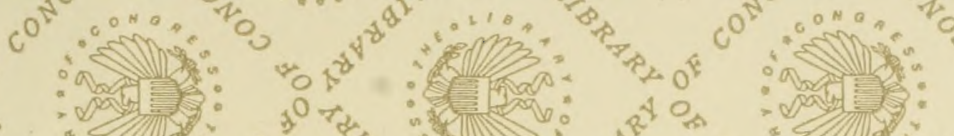

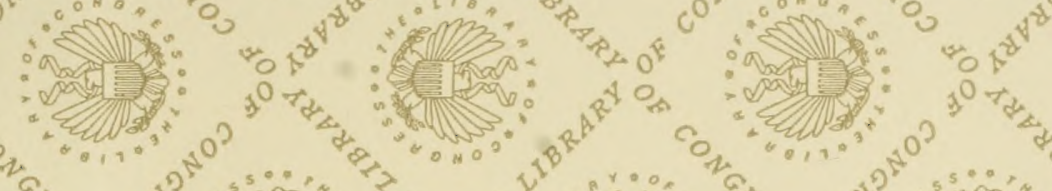

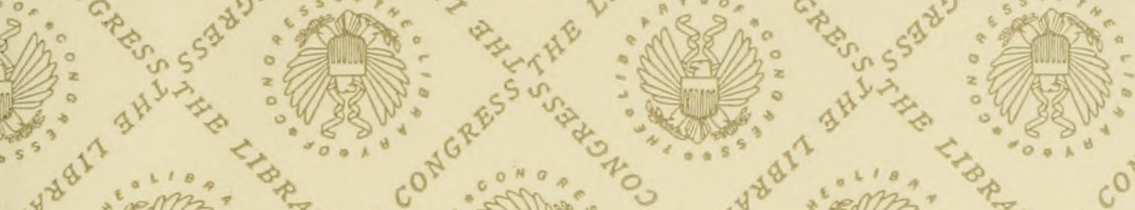

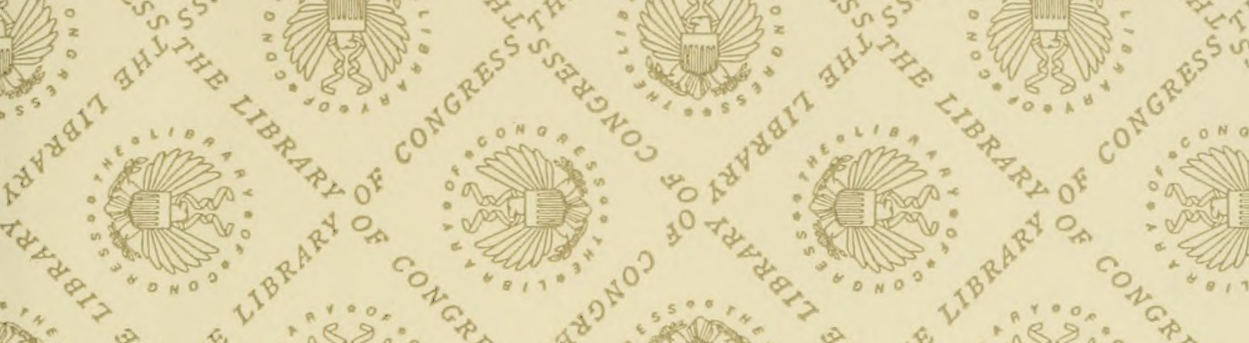

(2) (4)

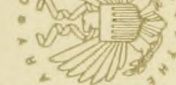

30

(a)

$8 x^{2}$

and:

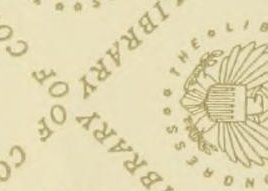

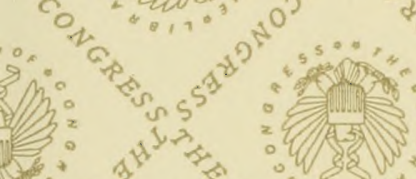

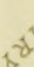

(<smiles>C1[C@H]2C[C@H]12</smiles>

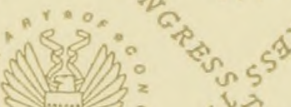

2.

$\sin _{\infty}$ 





\title{
7.395
503
}

\section{SOUTH PARK}

\section{ACTS}

OF THE

GENERAL ASSEMBLY RELATING TO THE SAME, AND THE COLLECTION OF THE ASSESSMENTS.

\author{
DECISIONS OF THE SUPREME COURT \\ RELATING THERETO.
}

\section{ORDINANCES}

SYNOPSIS OF IMPROVEMENTS 



\title{
SOUTH PARK
}

\author{
A C T S
}

OF THE

GENERAL ASSEMBLY RELATING TO THE SAME, AND THE COLLECTION OF THE ASSESSMENTS. DECISIONS OF THE SUPREME COURT
RELATING THERETO.

\section{ORDINANCES}

SYNOPSIS OF IMPROVEMENTS 


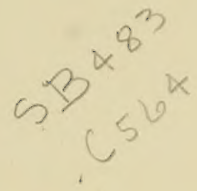

AUG 271906
0, of $D$.

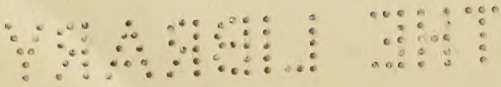




\title{
SOUTH PARK
}

\section{ORGANIZATION OF THE BOARD, AND ITS OFFICERS, \\ JULY Ist, 1875}

\author{
COMMISSIONERS \\ CHAUNCEY T, BOWEN \\ GEORGE W, GAGE \\ L. B. SIDWAY \\ PAUL CORNELL \\ JAMES MORGAN
}

\section{OFFICERS}

\begin{tabular}{|c|c|c|c|c|c|c|}
\hline PRESIDENT & . & . & & . & . & CHAUNCEY T. BOWEN \\
\hline *AUDITOR & . & - & & - & & GEORGE W. GAGE \\
\hline TREASURER & . & • & & & & J. IRVING PIERCE \\
\hline SECRETARY & $\cdot$ & · & - & - & & . H. W. HARMON \\
\hline COLLECTOR & . & & & - & . & . WM. L. GREENLEAF \\
\hline GEN'L SUPERIN & ITENL & & & - & . & . W. M. BERRY \\
\hline ATTORNEYS & - & & & & & . $\left\{\begin{array}{l}\text { AYER \& KALES, and } \\
\text { JAMES P. ROOT }\end{array}\right.$ \\
\hline NGINEER IN & HARC & & & & & . J. H. SAMS \\
\hline
\end{tabular}

*On the death of Mr. GAGE, Sept. 24th, 1875, the office of Auditor became vacant. Mr. Sidway has since been appointed to fill the vacancy. 


\section{INDEX AND REFERENCES}

PAGE

Original South Park Act. Private Laws 1869, Vol. I, p. 358.... 5 Supplemental and Amendatory Act. Private Laws 1869, Vol. I,

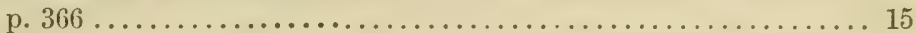

\section{DECISIONS}

People, ex rel., Wilson vs. Salomon. Reported in $51 \mathrm{Ills.,} \mathrm{p.} \mathrm{37...} 18$ People, ex rel., vs. Williams. Reported in 51 Ills., p. 57........ 33 Amanda S. Cook vs. South Park Commissioners. Reported in 61

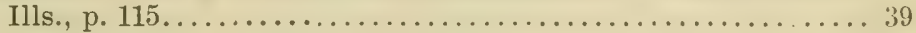

The People, ex rel., Henry B. Miller, etc., vs. P. H. Brislin, et al. 83 Francis B. Law vs. The People, ex rel., Henry B. Miller, etc..... 95 STATUTES, ETC.

General Park Act, applicable to South Park. R. S. 1875, p. 733. 49 Eminent Domain-Act concerning. R. S. 1875, p. $475 \ldots \ldots \ldots .60$ Revenue Laws, applicable to collection of assessment. R.S. 1875,

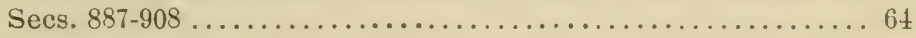

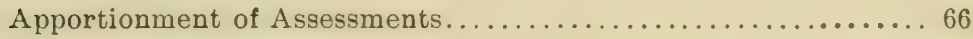

Ordinances for Government of the Park................. 69

Jurisdiction of Justices and Magistrates. R. S., p. 639, Sec. 14 . . 73

History of Organization and Progress................... 75

In Memoriam-George W. Gage...................... 81 


\section{SOUTH PARK}

Acts and Decisions of the Supreme Court of the State of Illinots relating thereto.

AN ACT to provide for the location and maintenance of a Park for the Towns of South Chicago, Hyde Park and Lake:

Section 1. Be it enacted by the People of the State of Illinois, represented in the General Assembly. 'That five persons, who shall be appointed by the governor of the State of Illinois, together with their successors, be, and they are hereby, constituted a board of public park commissioners, for the towns of South Chicago, Hyde Park and Lake, to be known under the name of the South Park Commissioners: and in case of the failure of any of said persons to accept such appointment, and to qualify theremder as hereinafter provided, within sitxy days after the passage of this act, the place of such person in said commission shall be thereby vacated, and it shall be the duty of a majority of the commissioners so accepting, to appoint some suitable person to fill the place thus made vacant, which appointment, when accepted by such nominee, shall constitute such person as a commissioner under this act. And a majority of said commissioners shall so continue to nominate until the board shall consist of five persons. Each of said commissioners, before entering upon the duties of his office, shall take an oath to well and properly discharge the duties of his office for the interest of the public, which oath shall be reduced to writing, subscribed to by him, and filed in the office of the county clerk of Cook county. They shall each give a bond in the penal sum of fifty thousand dollars, with one or more securities, to be approved by the judge of the circuit court of Cook county, to 
the treasurer of Cook county, conditioned for the faithful discharge of their duties under this act.

SEC. 2. As soon as convenient after the said board shall be constituted as aforesaid, the members thereof shall decide by lot, at a meeting to be called by any three of them, as to the respective terms for which each member shall hold his office; the number of lots shall equal the number of commissioners, and the person drawing the longest term shall serve for five years from the first day of March, A. D. 1869; the one drawing the next, shall serve for four years from said date; the one drawing the next, shall serve for three years from said date; and so on until the term of each one of said commissioners shall be definitely determined, each one serving for the length of time inscribed on the lot drawn by him-the last of said commissioners serving for the term of one year only from said first day of March, A. D. 1869. As soon as the term of office of each of said commissioner's shall be determined as aforesaisl, said hoard shall organize by electing one of their number as president, and one of their number as auditor; they shall also appoint a treasurer, prescribe his duties, and fix his compensation, who shall give bond for the faithful discharge of his duties in the penal sum of five hundred thousand dollars, with not less than three sufficient sureties, to be approved by the judge of the circuit court of Cook county. They shall also choose a secretary, who shall not necessarily be a commissioner, and who shall hold his office until his successor shall be appointed as hereinafter provided; and all officers appointed by the board shall be subject to removal at the pleasure of the board. The said board shall adopt a seal, and alter the same at pleasure; they shall keep a complete record of all their proceedings, which shall be open at all times for the inspection of the public. The said commissioners shall receive no compensation for their services, cxcept the president, who may, in the discretion of said board, have and receive such compensation as may be fixed as hereinafter provided, not to exceed three thousand dollars per annum. All vacancies occurring in said board shall be filled by the appointment of the judge of the circuit court of Cook county, when such vacancy or racancies shall occur. Said board of 
commissioners shall be a hody politic and corporate, and shall have and enjoy all the powers necessary for the purpose of this act.

SEC. 3. The president, auditor, treasurer and secretary, shall be elected annually by said board, at the annual meeting thereof, and shall receive such salary for their services as the said board shall from time to time determine, not exceeding, for each of said officers, the sum of three thousand dollars per annum.

SEC. 4. The said commissioners, by this act, are authorized and empowered to, and they shall, within ninety days after their organization, as aforesaid, or as soon thereafter as practicable, clect the following described lands, situated in the towns of South Chicago, Hyde Park and Lake, in Cook county, Illinois, to wit: commencing at the south-west corner of Fifty-first street and Cottage Grove avenue, ruming thence south along the west side of Cottage Grove arenue to the south line of Fifty-ninth street; thence east along the south line of Fifty-ninth street to the east line of Hyde Park avenue; thence north on Hyde Park avenue to Fifty-sixth street; thence east along the south line of Fifty-sixth street to Lake Michigan; thence southerly along the shore of the lake to a point due east of the center of section twenty-four (2t) in township thirty-eight (38) north, range fourteen (14); thence west through the center of said section twenty-four (2t) to Hyde Park avenue; thence north on the east line of Hyde Park avenue to the north line of Sixtieth street, so called, thence west on the north line of Sixtieth street, so called, to Kankakee avenue; thence north on the east line of Kankakee avenue to Fifty-first street; thence east to a point to the place of beginning; also a piece of land commencing at the south-east corner of Kinkaliee avenne and Fiftr-fifth strect, running thence west a strip two hundred feet wide adjoining the north line of Fifty-fifth street, along sail Fifty-fifth street to the line between ranges thirteen (13) and fourteen (14) east; thence north, east of and adjoining said line, a strip 200 feet wide, to the Illinois and Michigan Canal; also a parcel of land begimning at the south-west corner of Douglas place and Kankakee avenue, running thence south a strip of land 132 feet wide, along the west 
side of said Kankakee arenue, to a point 150 feet south of the south line of Fifty-first street; also a strip of land commencing at the intersection of Coltage Grove arenue and Fifty-first street, running thence east 100 fret in width on each side of the center line of Fifty-first street, to a point 100 feet east of the center line of Drexel avenue; also a strip of land extending north from the intersection of Fifty-first street with Drexel avenue, 100 feet in width on each side of the center line of said avenue to the north line of Forty-third street; thence northerly, a strip of land 200 feet in width, till it meets or interiects with Ehn street in Cleaverville; thence northerly along sid Elm street, 200 Jeet in width, west from the east line of said street, to its intersection with Oakwood avenue; which said land and premises, when acquired by said commissioners as provided by this act, shall be held, managed and controlled by them and their successors, as a public park, for the recreation, health and benefit of the pul)lic, and free to all persons forever, subject to such necessary rules and regulations as shall, from time to time, be adopted by said commissioners and their successors for the well ordering and government of the same.

SEC. 5. In case the said commissioners cannot agree with the owner or owners, lessees or occupants of any of the said real estate selected by them as aforesaid, they may proceed to procure the condemnation of the same in the manner prescribed in the act of the general assembly of the state of Illinois, contitled "An Act to amend the law condemning right of way for the purpose of internal improvements," approved June 22, 1852, and the acts amendatory thereof, the provisions of which said act, and the several acts amendatory thereof, are hereby extended to the park and park commissioners to be created by virtue of this act.

SEC. 6. When the title to the land selected for such park as herein provided, shall have been acquired by said commissioners, by gift, condemnation, or otherwise, it shall be the duty of such commissioners to make, acknowledge, and file for record in the office of the recorder of deeds for Cook county, a map, showing the said land, with a correct description, including section, township and range. 
SEC. $\%$ As soon as the amount required for the condemnation of the grounds selected for said park shall have been ascertained, by said commissioner's, with reasonable certainty, they shall apply to the judge of the circuit court of Cook county, for the appointment of three freeholders of the county of Cook as park assessors. 'The commissioners shall give notice in one or more of the daily newspapers published in the city of Chicago, of the time when such application will be made, and all parties interested may appear and be heard by the said judge, touching such appointment. At the time fixed for such application, the court, after hearing such persons as shall desire to be heard, touching such appointment, shall nominate and appoint three assessors for the purposes provided in this act. The said assessors shall proceed to assess the amount so ascertained upon property in the towns of South Chicago, Hyde Park and Lake, in Cook county, deemed benefited by reason of the improvement occasioned by the location of said park, as near as may be in proportion to the benefits resulting thereto: Provided, that the aggregate of said benefits is equal to or greater than the amount of said damages; and in case the aggregate of the benefits is less than the damages, then the balance of the damages over the benefits shall be from the fund provided for in section 8 of this act. Upon entering on the duties of their office, the said assessors shall make oath before the clerk of the said circuit court faithlully and impartially to discharge the duties of their office. 'They shall give at least ten days' notice in one of the said daily papers, of the time and place of their meeting for the purpose of making said assessment, and may adjourn such meeting from time to time until the same shall be completed. In making the said assessment the said assessors shall estimate the value of the several lots, blocks or parcels of land deemed benefited by them as aforesaid, and shall include the same, together with the amount assessed as benefits, in the assessment roll. All parties interested may appear before said assessors, and may be heard touching any matter connected with the assessment. When the same shall be completed, it shall be signed by the assessors, and returned to the said circuit court, and shall be filed by the clerk thereof. The assessors shall thereupon give 
at least ten days' notice in one of the said daily papers, of the filing of said assessment roll, and that they will, on a day therein named, apply to the said circuit court for confirmation of the same, which said notice shall be published at least ten days before the time fixed for such application. Said circuit court shall have power to revise, correct, amend or confirm said assessment, in whole or in part, and may make or order a new assessment in whole or in part, and the same revise and confirm upon like notice. All parties interested may appear before said circuit court, either in person or by attorney, when such application shall be made, and may object to said assessment, either in whole or in part, provided all objections shall be in writing, and shall be filed at least three days before the time fixed for the application, and shall specify the lot, block or parcels of land on behalf of which objection is made. After the confirmation of said assessment, the clerk of said circuit court shall file a copy thereof, under the seal of his said court, with the clerk of the county court of Cook county, and such assessment shall be a lien upon the several lots, blocks or parcels of land assessed for the benefits as aforesaid. Ten per cent. of the amount so ascertained shall be due and payable anmually, and the clerk of said Cook county court shall include in the general tax warrants for each year, until the whole sum shall be paid, for the collection of State and county taxes in the said towns of South Chicago Hyde Park and Lake, ten per cent. of the said assessments, in an apmopriate enlumn, to be temerl "south Park Arisesment," with the amount to be collected opposite the several lots, blocks or parcels of land assessed as aforesaid; and like proceedings in all respects shall be had for enforcing the collection of the same as is now provided by law for the collection of state and county taxes. The money collected under the provisions of this section shall be paid to the treasurer of Cook county, for which he and his sureties shall be responsible as fully as for any other moners by him received as treasurer of Cook county, and be held by him in the same manner and be subject to the same control and direction, as provided in this act for other moneys belonging to said corporation; and the treasurer of Cook county shall be entitled to receive one-half of one per cent. and no more, of 
said moneys as a full compensation for receiring and disbursing the same.

SEC. 8. For any deficiency arising through acquiring a title to said park, and for the payment of expenses of enelosing, maintaining and improving the park herein provided for, and the expenses, disbursements and charges in the premises, the said commissioners shall have power to loan or borrow, from time to time, for such time as they shall deem expedient, a sum of money not exceeding two millions of dollars, and shall have authority to issue bonds, secured upon the said park and improvements, which bonds shall issue under the seal of said commissioners, and shall be signed by said commissioners, and countersigned by the secretary of said board, and bear interest not exceeding seven per cent. per ammum; and it shall be the duty of said commissioners to keep an accurate register of all bonds issued by them, showing the number, date and amount of each bond, and to whom the same was issued, and said register shall at all times be open to the investigation of the public: and for the payment of the principal and interest of said bonds, the said park and improvements shall be irrevocably pledged, and the towns of South Chicago, Hyde Park and Lake, shall be irrevocably bound; and said bonds may be sold by said commissioners, upon such terms and for such prices as, in the judgment of said commissioners, can be obtained for the same in cash.

SE0. 9. The said board of park commissioners shall annually, on or before the 1st day of December in each year, transmit to the clerk of the county court of Cook county, an estimate, in writing, of the amount of money, not exceeding in any one year, three hundred thousand dollars, necessary for the payment of the interest on the bonds issued by said board, and that in addition thereto will be required for the improvement, maintenance and government of said park during the current year; and the said clerk shall proceed to determine what per cent. said sum is on the taxable property of said towns, according to the several assessors' returns for the respective year, and shall, in the next general tax warrants for the collection of State and county taxes in said several towns, set down the amount charge- 
able to the sereral persons, corporations, lots or parcels of ground, in a separate or appropriate columm, and shall receive such compensation as now allowed by law; and the collectors respectively shall proceed to collect the same in the manner now provided by law for the collection of State and county taxes; and all the provisions of law, in respect to the collection of State and county tares, and proceedings to enforce the same, so far as applicable, shall apply to said assessments and taxes. The said sum of money shall be placed by the treasurer of the said county of Cook, to the credit of said board of park commissioners, and shall be drawn by said board from the county treasury by warrant, signed by the president and secretary of the board, and countersigned by the auditor, to be appointed as aforesaid, and in no other way the aplointment of such anditor or comptroller having heen first duly certified hy such president and secretary, and filed in the office of said treasurer of Cook county.

SEC. 10. It shall be lawful for said commissioners to vacate and close up any and all public roads and highways, excepting railroads, which may pass through, divide or separate any lands selected or appropriated by them for the purpose of a park; and no such road shall be laid out through said park except as the said commissioners shall lay out and construct.

SEC. 11. No one of the said commissioners shall be interested, either directly or indirectly, in any contract entered into by them with any other person; nor shall they be interested, directly or indirectly, in the purchase of any material to be used or applied in and about the uses and purposes contemplated in this act. And it shall be a misdemeanor for any commissioner to be directly or indirectly interested, or in any way pecuniarily interested in any contract or any work of any kind whatever, connected with said park.

SEC. 12. The said commissioners, or either of them, may be removed from office by the Judge of the circuit court of Cook county, upon the petition presented to him in term time or in vacation, by one hundred freeholders of said towns of South Chicago, Hyde Park and Lake, if it shall appear, after hearing the proof before said judge, that the said commissioners, or 
either of them, have been guilty of mistemeanor or malfeasance in office under this act; and if the said jutge shall remore any two or more of said commissioners from office for any cause, before the expiration of their term of office, he is hereby empowered to appoint others in their stead, who shall fill such offices for and during the unexpired term of such commissioners so removed.

SEc. 13. The said board shall have the full and exclusive power to govern, manage and direct said park; to lay out and regulate the same; to pass ordinances for the regulation and gorermment thereof; to alpoint such engineer's, surverors, clerks and other officers, including a police force, as may be necessary; to define and prescribe their respective duties and authority; fix the amount of their compensation; and generally, in regard to said park, they shall possess all the power and authority now by law conferred upon, or possessed by the common council of the city of Chicago, in respect to the public squares and places in said city; and it shall be lawful for them to commence the improvement of said park as soon as they have obtained one hundred acres of the premises herein described.

SEc. 14. The office of any commissioner under this act, who shall not attend the meetings of the boards for three successive months, after having been duly notified of said meetings, without leave of absence from said board, may, by said board, be declared vacant.

SEC. 15. The real estate and personal property of said corporation shall be exempted from taxation and assessment.

SEC. 16. All moneys belonging or to belong to any park fund now in existence or hereafter to be created, and all bonds, and the proceeds from sales thereof now authorized or hereafter to be authorized to be issued by the city of Chicago for park purposes, in or to which the South Division of the city of Chicago may now or shall hereafter be entitled to a distributive share, shall be devoted and applied to the purchase or maintenance and improvement of the park contemplated and created by this act, under the direction and control of the commissioners provided for in this act.

SEC. 1\% The bonds to be issued under this act may be re- 
ceived in payment of any assessment, whether such bond or assessment shall have heceme due or not, ugron such terms ats shall he fair, just and expuitable: and upon the payment of any assessment, the land upon which the same is assessed shall be free from any lien or liability to pay the same; and such payment shall be reported to the county clerk of Cook county, and entered upon the record of assessment.

SEC. 18. There shall be an election held in the torns of South chicago, Hycle Park and Iake, on the fourth Tuestay in March next after the passage of this act, at which election the legal voters voting at such clection shall vote for or against this act. The tickets shall be printed or written, "For Park" or "Against Park;" and if a majority of the votes cast on the subject of park shall be "For Park," then this act shall take effect and be in force, but not otherwise. The clerk of the county ("ourt of cook county shall designate the places of holing such election, and give notice thereof in one or more of the daily papers published in the county of Cook, at least six days preweding such eleretion, and shall sulply the judges thereof with the necessary books, papers and boxes as in other cases of election, and there shall be one polling or voting place in each voting precinct in said towns, as the same were fixed at the last general election in the county of Cook. The persons who acted as judges or inspectors of election in the several precincts of said towns, at the last general election in Cook county, shall be the judges or inspectors of this election. In case the judges or inspectors of elections shall not attemel at the time for opening the polls, such judges or inspectors shall be chosen by the legal voters present. The clerks shall be appointed as provided in elections for county officers. The polls shall be opened and closed, and the election conducted as elections for county officers. All legal voter's of said towns shall be entitled to rote at such election, without any new registration; and the judges or inspectors of such election shall we the registry list made for the general election in Norember, 1868 ; Provided. That whenerer any person whose name is not on the registry list shall offer his vote at such election, the judges or inspectors shall require the same evidence of his qualifications as now provided by law. 
The side judges of election shall inmerliately alter the elosing of the polls, count the ballots, fill out and sign the returns and tally-sheets, as now provided by law in all other elections, and return the poll books and ballots to the clerk of the county court, as in other cases of election. The votes shall be canvassed in the manner provided by law for the election of state and county officers. The clerk of the county court of Cook county shall immediately after such canvass, cause a certificate of the result of such election to be filed in the office of the secretary of state, which shall be conclusive evidence of the result of said election.

SEC. 19. This act shall be a public act, and shall take effect and be in force from and after its passage.

Approved February 24, 1869.

IN ACT amendatory of and supplementary to an act to provide for the location and maintenance of a Park for the towns of South ('hicago, Iyde Park and Lake, approved February D4, 1869 .

Section 1. Be it enacted by the People of the State of Illinois, represented in General Assembly, That the portion of the fourth section of the act to which this is amendatory and supplemental, which is in the words "A piece of land commencing at the south-east corner' of Kankalkee arenue and Fifty-fifth street; running thence west, a strip two hundred feet wide adjoining the north line of Fifty-fifth street," is hereby amended by substituting in lieu thereof the words "A piece of land commencing at the north-east corner of Kankakee avenue and Fifty-fifth street, running thence west a strip two hundred feet wide south of and adjoining the north line of said Fifty-fifth street."

SEC. 2. The bonds authorized to be issued by the act of which this is amendatory and supplemental, may be jisued, sold, and the proceeds applied for acquiring said lands, and for any and all purposes in the said act mentioned. Said bonds shall be retired and canceled as fast as the money for that purpose can be obtained, by the collection of the money due upon the special assessment provided for in section seven of the act hereinbefore mentioned, and a sufficient amount of any bonds that 
may be issued by the city of Chicago under any law now in force or hereinafter ('nacted, and reepived by said commissioner's, shall be applied to the purpose of retiring the bonds authorized by said act.

SEC. 3. The ninth section of said act is hereby so amended that the words "during the current year," shall read "during the next succeeding year."

SEC. 4. That the twelfth section of said act be and the same is hereby amended so as to read as follows: The said commissioners, or either of them, may be removed from office by the judge of the circuit court of Cook county, upon the petition presented to him in term time, or in vacation, by one hundred freeholders of said towns of South Chicago, Hyde Park and Lake, if it shall appear after hearing proof before said judge, that the said commissioners, or either of them, have been guilty of misdemeanor or malfeasance in office under this act; and if the said judge shall remove any one or more of said commissioners from office for any cause before the expiration of their term of office, he is hereby authorized and empowered to fill the vacancy or vacancies thus created by appointing other commissioners in their place, who shall serve during the unexpired terms of the commissioners so removed.

SEC. 5. The commissioners to be appointed under said act are hereby rested with the same powers and duties as are conferred by said act in wation to lands derignated for parks, over all strects rumning longitudinally along and arjoining any and all of the proposed parks, or strips of land designated in said original act, as are conferred he said act in relation to such parkis and strips of land, as may be necessary to improve and keep in repair the same, in connection with the said parks or strips of land without obstructing the fences or other structures, free access to the said strecets from existing roads and streets, and by owners of land abutting on the same.

SEC. 6. The elections held in the towns of South Chicago, IIyde Park and Lake, on the twenty-third day of March, A. D. 1869 , under and hy virtue of the eighteenth section of the act to which this is an amendment, are hereby legalized and confirmed, and said act shall be held and deemed to have been reg- 
ularly and legally adopted by the legal voter's of said towns, and shall remain in full force and effect, and shall be liberally construed in all courts, with a view to carry out and enforce the intent and meaning of the same.

SEC. 7. This act is hereby declared a public act, and shall take effect, and be in full force from and after its passage.

$$
\begin{aligned}
& \text { F. CORWIN, } \\
& \text { Speaker of the House of Representatives. } \\
& \text { J. DOUGHERTY, } \\
& \text { Speaker of the Senate. }
\end{aligned}
$$

Approved April 16, 1869.

JOHN M. PALMER, Governor. 


\title{
DECISION BY SUPREME COURT OF ILLINOIS
}

\author{
'THE SOUTH PART.
}

At a Supreme Court, begun and held at Mount Vernon, on Tuesday, the first day of June, in the year of our Lord one thousand eight hundred and sixty-nine, within and for the First Grand Division of the State of Illinois: Present-Sidney Breese, Chief Justice; Charles B. Lawrence, Justice; Pinkney H. Walker, Justice.

The People on the relation of John M. Wilson, et al. vs. E. S. Salomon, Clerk of Cook County Court-Apptication for Mandamus.

\section{[Opinion by Breese, C. J.]}

This is an application by John M. Wilson and others, styling themselves south Park ('ommisioners, for a peremptory mandamus against Edward S. Salomon, the clerk of the county court of Cook county, to compel him, as such clerk, to receive and file in his office forthwith a certain estimate transmitted to him by the petitioners of the amount of money that they allege will be required to be raised by taxation the next succeeding year for the improvement, maintenance and government of the south park; and to compel him to proceed to lery or assess the amount certified in such certificate upon the taxable property in the towns of South Chicago, Hyile Park and Lake, in the next general tax warrants for the collection of State and county taxes in those towns. It is stipulated that the petition shall stand in the place of an alternative writ to which a motion to quash has been interposed, so that the question whether certain acts of the General Assembly mentioned in the petition are so far valid that the amount certified to the respondent, by the south park commissioners, ought to be levied and collected as a tax as provided in those acts, and the further question, whether the relators are precluded of their remedy by mandamus, by reason of a pendency 
of a suit by injunction particularly mentioned in a stipulation on file, may be fully presented and decided.

The petition alleges that on the twenty-fourth of February, 1869, an act of the General Assembly of this State was duly approved, entitled "An act to provide for the location and maintenance of a park for the towns of South Chicago, Hyde Park and Take."

By section one of this act the Governor of the State was required to appoint five persons, who, and their successors, are constituted a board of public park commissioners, to be known under the name of the South Park Commissioners; each of the commissioners, before entering upon the duties of his office, was required to take an oath well and properly to discharge the duties of his cffice for the interests of the public, and to give a bond in the penal sum of $\$ 50,000$, with one or more sureties, to be approved by the judge of the circuit court of Cook comnty, payable to the treasurer of Cook county, conditioned for the faithful discharge of their duties under the act.

By section two provision is made for fixing the terms of office of the several members, and for organizing, by the election of one of their number as president, and one of their number as auditor, and by the appointment of a treasurer, who should be required to give a bond, with not less than three sufficient sureties, for the faithful discharge of his duties, in the penal sum of $\$ 500,000$, to be approved by the judge of the same circuit court. A secretary was required to be chosen, a seal to be adopted (which they could alter at pleasure), a record to be kept of their proceedings, no compensation allowed the commissioners except to the president, vacancies to be filled by appointment of the judge of the circuit court of Cook county, and the board is declared a body politic and corporate, and to have and enjoy all the powers necessary for the purposes of the act.

These purposes are declared by the fourth section, which are the selection of certain described lands by the commissioners, within ninety days after their organization, situate in the towns of South Chicago, Iyde Park and Lake, which lands, when acquired, are to be held, managed and controlled by them and their successors as a public park, for the recreation, health and 
benefit of the public, and free to all persons forever, subject to such necessary rules and regulations for the well ordering and government of the same as the commissioners or their successors may adopt.

The fifth section gives the commissioners power, if they and the owners of any of these lands cannot agree, to proceed to cordemn them.

Provision is made by section seren for the appointment of assessors to assess the benefits and damages.

The eighth section is as follows:

"For any deficiencies arising through acquiring title to said park and for the payment of the expeness of enclosing, maintaining and improving the park herein provided for, and the expenses, disbursements and charges in the premises, the said commissioners shall have the power to loan or borrow, from time to time, for such time as they shall deem expedient, a sum of money not exceeding two millions of dollars, and shall hare authority to issue bonds secured upon the said park and improvements, which bonds shall issue under the seal of said commissioners, and shall be signed by said commissioners, and countersigned by the secretary of said board, and bear interest not exceeding seven per cent. per annum; and it shall be the duty of said commissioners to keep an accurate register of all bonds issued by them, showing the number, date and amount of each bond, and to whom the same was issued, and said register shall at all times be open to the investigation of the public; and for the payment of the principal and interest of said bonds, the said park and improvements shall be irrevocably pledged, and the tomns of South Chicago, Hyde Park and Lake shall be irrevocably bound; and said bonds may be sold by said commissioners, upon such terms and for such prices as, in the judg. ment of said commissioners can be obtained for the same in cash."

Section nine provides as follows:

"The said board of park commissioners shall, anmually, on oi" before the 1st day of December in each year, transmit to the clerk of the county court of Cook county an estimate, in writing, of the amount of money, not exceeding in any one year three 
hundred thousand dollars, necessary for the parment of the interest on the bonds issued by said board, and that in addition thereto will be required for the improvement, maintenance and government of said park during the current year; and the said clerk shall proceed to determine what per cent. said sum is on the taxable property of said tomns, according to the sereral assessors' returns for the respective year, and shall, in the next general tax warrant for the collections of State and county taxes in said several towns, set clown the amount chargeable to the sereral persons, corporations, lots or parcels of ground, in a separate or appropriate column, and shall receive such compensation as now allowed by law; and the collectors respectively shall proceed to collect the same in the manner now provided by law for the collection of State and county taxes; and all the provisions of law in respect to the collection of State and county taxes, and proceedings to enforce the same, so far as applicable, shall apply to said assessments and taxes. The said sum of money shall be placed by the treasurer of the said county of Cook to the eredit of said board of park commissioners, and shall be drawn by said board from the county treasury by warrant signed by the president and secretary of the board, and countersigned by the auditor to be appointed as aforesaid, and in no other way; the appointment of such auditor and comptroller having been first duly certified by such president and secretary, and filed in the office of said treasurer of Cook county."

Section thirteen is as follows:

"The said board shall have the full and exclusive power to govern, manage and direct said park; to lay out and regulate the same; to pass ordinances for the regulation and government thereof; to appoint such engineers, surveyors, clerks and other officers, including a police force, as may be necessary; to define and prescribe their respective duties and authority; fix the amount of their compensation; and, generally, in regard to said park, they shall possess all the power and authority now by law conferred upon, or possessed by, the common council of the city of Chicago, in respect to the public squares and places in said city; and it shall be lawful for them to commence the improvement of said park as soon as they have obtained one hundred acres of the premises herein described." 
Section eighteen prorides for an election to be held in these towns on the fourth Monday of March next alter the passage of the act, at which election the legal voters were required to vote for or against the act, the tickets to be printed "For Park," and "Against Park," and if a majority of the rotes cast be "For Park" then the act is to take effect and be in force, and not otherwise. Ample provision is made for holding the polls and for canvassing the rotes, as for the election of State and county officers; and the clerk of the county court was required, immediately after the canvass, to cause a certificate of the result to be filed in the office of the secretary of state.

The nineteenth section makes the act a public act, and to take effect and be in force from and after its passage.

By an amendatory and supplemental act, approved April 16th. 1869 , it was provided, among other things, by section 2 , that the bonds authorized to be issued by the act of which this is amendatory and supplemental, may be issued, sold, and the proceeds applied for acquiring said lands, and for any and all purposes in the said act mentioned. Said bonds shall be retired and canceled as fast as the money for that purpose can be obtained by the collection of the money due upon the special assessment provided for in section seven of the act hereinbefore mentioned, and a sufficient amount of any bonds that may be issued by the city of Chicago under any law now in force, or hereafter enacted, and received by said commissioners, shall be applied to the purpose of retiring the bonds authorized by said act.

The third section amends the ninth section by substituting the next succeeding year for the current year.

- The sixth section confirms and legalizes the election held on the $23 \mathrm{~d}$ of March, as required by section 18 of the original act.

Section seven declares this act to be a public act, and to be in force from and after its passage.

These portions of the original and supplemental acts are those upon which the questions arise, and which we consider necessary to be examined in order to a proper understanding of the case.

The petition alleges that this act was duly submitted to the legal roters of the towns of South Chicago, Hyde Park and Lake, at an election held within them, on the day specified in the act, 
for their approval or rejection, at which election a large majority of the rotes cast in each of those towns was in favor of the park provided for in the act, a certificate of which was filed by the clerk of the county court with the secretary of state. It allege: the corporation created by the act had duly organized, having in all things complied with the provisions of the act creating itthat the lands had been selected, and that they had purchased and acquired the title to 100 acres and upwards of the lands selected, and they allege they are now negotiating for the purchase of, and expect soon to acquire the title to, the residue; that they have issued and sold bonds to the amount of $\$ 125,000$ to provide money to pay for these lands, and that they expect and intend soon to issue and sell a large additional amount of bonds for the same purpose.

It is further alleged that on the 24th of May, 1869, they, as the board of South Park Commissioners, passed a preamble and resolution, which was duly entered on their record, a certified copy of which, under the seal of the board, they did on that day transmit to the respondent as clerk of the county court of Cock county, accompanied by a communication in writing, signed by all the members of the board, which preamble and resolution is as follows:

"Wherzas, This board is required by its act of incorporation and a subsequent act of the General Assembly amendatory thereof and supplementary thereto, to transmit annually on or before the first day of December in each year to the clerk of the county court of Cook county an estimate, in writing, of the amount of money, not exceeding in any one year $\$ 300,000$, necessary for the payment of the interest on the bonds issued by said board, and that in addition thereto will be required for the improvement, maintenance and government of the park provided for in said acts during the next succeeding year.

"Be it therefore Resolved, That the sum of $\$ 300,000$ be, and the same herely is designated for such purposes which this board hereby estimates as necessary for the same; and that this amount be certified in writing by the secretary of this board, under the seal thereof, to the clerk of the county court of Cook county, as the estimated amount of money that will be necessary and re- 
quired by this bard during the next sueceding year for the purposes above mentioned; and further, that the said clerk be requested to assess the same upon the taxable property of the towns of South Chicago, Hyde Park and Lake, in the next general tax warrants for the collecting of State and county taxes in said several towns, agreeable to the provisions of the ninth section of the act first above referred to, entitled 'An act to provide for the location and maintenance of a park for the towns of South Chicago, Hyde Park and Lake,' approved Feb. 24, 1869, as amender ly the act amendatory of and supplementary to said first-named act, approved April 16, 1869."

The communication from the board accompanying the above was of the following tenor:

$$
\text { Cincago, MIay 24, } 1869 .
$$

\section{To Gen. Edward S. Salomon,}

\section{Clerk of the County Court of Cook County:}

Sir: The undersigned, constituting the board of South Park Commissioners, transmit herewith a certified copy of a preamble and resolution passed by the said board on the 24 th instant, specifying the estimated amomt of money that will be necessary and required during the next succeeding year for the payment of the interest on the bonds issued by said board, and for the improvement, maintenance and government of the park therein referred to. 'The estimate, as you will perceive, is $\$ 300,000$.

You will please place this communication on file in your office; and you are hereby requested to assess the amount above mentioned, for the purposes herein specified, on the taxable property of the towns of South Chicago, Hyde Park and Lake, in the next general tax warrants for the collection of State and county taxes in said several towns, agreeably to the provisions of section 9 of the act approved Feb. 2t, 1869, entitled "An act to provide for the location and maintenance of a park for the towns of South Chicago, Hyde Park and Lake," as amended by the act amenelatory of and supplementary to said first-named act, approved April 16, 1869. Very respectfully, \&c.

This communication, with the preamble and resolution of the board, was returned by the clerk on the 25th of May, with a communication from him, in which he says, "as a suit has been 
commenced against him, as well as the commissioners, in the superior court of Chicago, to enjoin him from levying the tax referred to in the resolution, he cannot consistently receive these documents, and declines to place either of them on file in his office. He further says he has decided not to lery or assess a tax for the purpose specified until he is required by a court of competent jurisdiction : and he desires his letter to be considered as an official and positive refusal on his part to comply with the requests of the commissioners."

The stipulation to consider the petition as an alternative writ, the motion to quash performs the same office as a general demurrer to the writ, and brings the law of the case fully before us. All the facts, which are well pleaded, are admitted by the motion, and the question is distinctly raised, is there enough shown in the petition to entitle the relator to a peremptory writ of mandamus?

The refusal of the clerk to do the duty enjoined upon him by the ninth section of the act is positive and peremptory, and we are to inquire, is he justified therein by any want of validity in. the act itself; for it is upon that, and that alone, the justification is claimed.

The respondent makes several points of objection to granting the writ, which we will now consider.

He denies that the relators are invested by the acts eited with authority to issue and sell bonds which shall be a charge upon the towns of south ('hicago, Hyde Park and Lakie, no legal and competent means having been provided for their payment.

The argument is, that the manner in which the power to acquire the land is proposed to be exercised is in violation of section five of article nine of our constitution.

The provision is that the corporate authorities of counties, townships, school districts, cities, towns and villages, may be vested with power to assess and collect taxes for corporate purposes; such taxes to be uniform in respect to persons and property within the jurisdiction of the body imposing the same, and the legislature shall require that all the property within the limits of municipal corporations shall be taxed for the parment of debts contracted under the authority of law. 
We have held in Hayward $v$ s. the St. Clair and Monroe Sewer and Drainage Company, decided at the last January term, and in the case of the people, ex relatione McCagg, $v s$. the Mayor, \&c., of Chicago, decided at the present term, that this clause must be construed as a limitation upon the power of the legislature to authorize any other than corporate authorities to assess and collect local taxes. But while this provision limits the objects of local taxation in corporate purposes, and the delegation of the power of taxation to the corporate authorities of counties, townships, school districts, cities, towns and villages, it clearly does not prevent the legislature from creating districts by the union of two or more towns in the same county for any special township purpose, such as lunilding a bridge, improving a ricer on which they may be situate, or constructing a canal, with the consent of those towns, and exercising for such district an authority, likewise with their consent, to which shall be granted all the necessary powers of taxation for the construction of the improvements and for their government and control.

By our constitution, taxation is apportioned upon property by the rule of uniformity, and to do this there must be taxation districts. A State tax is apportioned throughout the State as a county tax is throughout a county, or a city tax is throughout a city, while in the case of a mere local improvment, such as a public park, benefiung more immediately particular towns, where is the constitutional incompetence of the legislature to be found to arrange those towns into a special taxation district, within which the expense shall be apportioned, and whose people and property shall bear the burden they have themselves imposed? If the legislature has power, for any purpose they may deem beneficial, to abstract from the powers they have granted to a municipal corporation, and to curtail their territorial juristiction-and this is not denied-what reason can be urged why they should not, with the assent of the people to he affected by the measure, place over them an authority for a special purpose with the powers granted to the relators?

To say such an act is forbidden by the constitution is not enough. The prohibition must be found either in the expresi letter of that instrument or in its spirit and true intention and 
meaning. Considering, then, that corporate authorities of counties, \&c., can alone assess and collect taxes for corporate purposes, it by no means follows, that the legislature cannot, should the public exigencies require it (of which they must be the judge) establish districts by the union of two or more municipal corporations, and place their government entirely under the control of the corporate authorities of such districts, bestowing upon them, among others, the taxing power?

The whole legislative power of the State is conferred by the constitution upon the General Assembly, composed of two houses, the members of both to have certain qualifications, and to be elected by the people. It follows, therefore, that every subject not withdrawn from them by the constitution, and which is within the scope of civil government, can be dealt with by that body; and as it may act upon the State at large, by general laws affecting the whole country and all the people, so it may in its discretion, there being no prohibition expressly made or necessarily implied, make special laws to relate only to separate districts or portions of the State.

The members of the two houses are the constitutional agents of the public will in every distriet or locality of the State, and they may therefore so arrange the porrers to be given and executed therein as convenience, the efficiency of administration and the public good may seem to require, by committing some functions to local jurisclictions already established, or by establishing local jurisdictions for that express purpose.

The clause in the ninth article on which so much stress is laid, that the legislature may vest the corporate authorities of counties, cities, etc., with the power to assess and collect taxes, does not confine the legislature to any particular corporate authorities or any then known instrumentalities of that character. The instrument was made for all time, with full knowledge that the public necessities might require the creation of various and dissimilar corporate authorities, and to be imbued with administrative functions of a nature which could not be properly exercised by any known and existing corporate authority.

There is no prohibition which we have been able to discover, and we have been pointed to none, against the creation by the 
legislature of every conceivable description of corporate authority, and, when created, to endow with all the faculties and attributes of other pre-existing corporate authorities. Thus, for example, there is nothing in the constitution of this State to prevent the legislature from placing the police department of Chicago, or its fire department, or its water-works, under the control of an authority which may be constituted for such purpose by a rote of the people, and endow it with power to assess and collect taxes for their support, and confide it to their control and government. Section five of article nine would not be violated thereby, because the authority thus established would be a corporate authority, and the purposes for which taxes conld be assessed are undeniably corporate.

The relators are made a body politic and corporate, with perpetual succession and with a seal, and, though appointed by the governor, they are a corporate authority within the meaning of the constitution, as the people of the torms named have consented by their rotes to the mode of appointment. By their votes they have, by a large majority, adopted this act, thus making the relators as commissioners corporate authorities, mro hac vice, for the purposes of this park, and have consented to the creation of this debt. We lay no stress upon the fact that the commissioners are nominally a corporation, for we do not hold it is in that capacity they can issue bonds or levy taxes to bind the people of these towns, but as township or corporate authorities, whose appointment has been assented to by the people within their jurisdiction.

The constitution nowhere commits corporate objects or purposes irrevocably to authorities now existing, nor does it prohibit the committal of them to such corporate authority as may be called into life by the same law which creates the subject and commits it to their jurisdiction.

The union of these towns was for a special purpose, and outsicie of that purpose. they are left with all their functions unclisturbed precisely as they existed before the passage of the law. Establishing them, with their consent, as a park district, deprived them of none of the franchises bestowed on them as towns, and eurtailed in no degree the fair proportions of either of them. 
The manifest distinction, in brief, between this case and that relating to Lincoln Park is this: In that wase the legislature undertook to compel the people of Chicago to incur a debt without the consent either of the people of the city, or of their corporate authorities, for it is impossible to hold that the commissioners of that park were corporate authorities of the city of Chicago. In this case the people of these three towns, by voting for the law, have made the commissioners corporate authorities of such towns, and empowered them to assess the requisite tax upon the property of the towns. The tax is really self-imposed by means of agents not directly named by the people of these towns, but named by the governor by virtue of an authority conferred by their vote.

We come now to consider the other objections made by the respondent's comsel to this act.

One of the counsel for respondent asks, of what character is the corporation, thus endowed with extraordinary, unheard of and unknown powers and privileges? and after defining the several kinds of corporations, he asks, to which of these divisions of public corporations does the South Park Commissioners belong? The answer is ready and obrious. By the vote of the people within the jurisdiction of their action they became a corporate authority quasi municipal, the object of their creation being of a municipal character, and of that alone. They became a public municipal corporation, and herein is found the answer to a prominent objection made by another of the counsel for respondent, based upon the fifteenth section of the act, which provides "that the real estate and personal property of said corporation shall be exempted from taxation and assessment." This, the counsel insists, is in the very teeth of the second clause of article nine. which declares that the "general assembly shall provide for levying a tax by valuation, so that every person and corporation shall pay a tax in proportion to the value of his or her property." It is argued that this park property belongs to these commissioners as a corporation. This is so by terms of the act. 'They hold the fee, but the usufruct is in the public, but holding it they hold it as a public corporation for public purposes, and was it ever heard that the property real or personal of 
a public municipal corporntion was subject to taxation? Is Union or Jefferson Park, in the city of Chicago, assessed for general taxes? Are their water-works so assessed, and their public squares and fire-engines, and other articles of personal property in their possession and ornership?

The corporations aimed at by the clause in question are prirate, not public, corporations; and such is the universal understanding.

It is further objected that the fact that a majority of the votes of the three towns has been given to this act imparts to it no additional validity, for by the terms of the act it might be that one of the townships, by its large rote, could dominate over the other two, and thus subject the minority towns to an onerous burthen imposed without their consent. This might be so, and if so, the case would be like the case of Lincoln Park, in which we held it contrary to the plain behests of the constitution to impose a local burthen of such magnitude upen an unwilling people without first obtaining the consent of the people to its imposition. When a similar case shall arise, the decision will be doubtless the same; but the facts admitted by the pleadings show a majority of the rotes of each of the towns was cast in favor of the act.

But it is urged that this assent of the people amounts to nothing; that the legislature had not the power so to submit the cnactment of a law to the popular vote; that as the entire act is submitted to the decision of the people of the towns, it is not a laiv within the meaning and sense of the constitution. He insists that such an act is legislation; that the people, by their rotes, make the law, when that power is exclusively confided to the general assembly.

This is not an open question here. Its discussion is precluded by the decision of this court in the case of The People, \&c., vs. Reynolds. 5 Gilmans, 1.

That was a case where the legislature had passed an act for the division of Gallatin county and the formation of a new county from the same territory, but to take effect only on the contingency that a majority of the rotes given should be cast in favor of such division. This same objection was made that the law 
was not an emanation of the legislative will, but that of the roters of the county sought to be divided. Very able arguments were made in support of the objection, which it is not necessary to state in detail, it being sufficient to say they covered the whole ground and fully exposed the objection in its whole length and breadth.

In a long and very able opinion by the late distinguished Chief Justice of this court, then Justice Caton, the constitutionality of the act was maintained, in which his associates concurred. The general proposition was discussed with great ability, that acts of the general assembly are not of necessity absolute, but may be so framed as to depend upon some future event or contingency for taking effect. That the act in question was complete when it left the legislature, although its principal movisions were to take eflect upon a contingency, the determination of which did not depend upon the exercise of the legislative power's by the people, but upon an expression which they were authorized to make, rather in the execution than in the enactment of the law-an expression to be made in a legitimate and ordinary way. The court say, if we take the action of all past legislatures as determining what may and should properly be done in the exercise of legislative powers, we see that while they are bound to make the laws, yet those laws need not be absolute nor make every provision for doing that which they may authorize to be done. While all must be done under their sanction, yet they need not do all nor command all. A law may depend upon a future event or contingency for its taking effect, and that contingency may arise from the voluntary act of others. Of this class, the court say, are all laws creating private corporations, and a very large proportion of the laws creating municipal corporations. If we say that this is an unauthorized delegation of legislative power, we forget what is a proper and legitimate cxercise of that power. If the saying be true that the legislature cannot delegate its power, it is only in its most general sense. We may well admit that the legislature cannot relegate its general legislative authority, still it may authorize many things to be done by others which it might properly do itself. "The legislature may pass all the laws requisite for the government of a particular city or 
township or school district: and who will cloubt the propriety of its authorizing this to be done by the people within the limits of the city, town or district, by their local representatives, or even directly? This is making laws, and laws, too, of as binding efficiency as if passed directly by the legislature."

The case is square on the point now under discussion, and necessarily disposes of it.

For a most exhaustive discussion of this subject, we refer to the cases of Alcom v. Hawen, and the same v. Hill, (38 Mississippi, 652), where all the authorities, pro and con, are collated and commented upon with signal ability, and wherein a decision was pronounced in conformity to that in The People v. Reynolds, supra. In these cases it was held that the power to enact laws necessarily inchuded the right in the law-making power to retermine and prescribe the conditions upon which the law in al given case shall come into operation or be defeated; and this contingency may as well be the result of the rote of the people of the locality to be affected by the law as any other.

The law of this case was discussed by the counsel and court with great power and ability, and may be read with profit and instruction.

The remaining point is, the effect of the pendency of the chancer suit to enjoin these relators from proceding under this law.

In the case of the people on the relation of Mitchell v. Warficld (20 Illinois, 160), which was a contest about the removal of the county seat of Saline county, and where a mandamus was applied for to compel certain official acts to be done by the respondent at the county seat, so deemed by the relator, and in the case of The Pcople ex rel., de., v. Wiant, decided at September trum, 1s68, which was also a contest growing out of the removal of the county seat of Du Page county, where a mandamus was applied for to compel the county treasurer to keep his office at the new county seat, and in both of which cases bills of injunetion had been filed, and in which were contested factr; we said, as the parties had commenced proceedings in another tribunal, to obtain an adjudication of the question, this court would not, except in extraordinary cases. interfere by mandamus. In those 
cases, facts wore contested; in this there are no contested facts, the whole issue being on questions of pure law.

As the granting a mandamus is a matter of discretion with the court, it was refused in the cases cited, because it was the opinion of the court the matters in controversy could be well determined in the suits pending.

But looking at the nature of questions involved in this case, we are satisfied they cannot be appropriately or finally determined in the suit pending, and complete justice done therein to all the parties; for, howerer the pending case may be determined, it will be no bar to a suit of the same nature brought by another property owner, and so on until the list of owners is exhausted, and the duties cast upon the relators by the law must remain unperformed for an indefinite time. Justice cannot be done to them as public functionaries, nor to the public, by the determination of that suit, in whatever way it may be decided, as it would dispose alone of that case, leaving the opportunity open of bringing other suits of the same kind in endless succession.

In conclusion, with the best light we have, we are satisfied the relators have shown a clear legal right to the writ for which they pray, and that they have no other adequate remedy to meet the exigencies of the case, and accordingly disallow the motion to quash, and direct a peremptory mandamus to issue, as prayed.

At a Supreme Court, begun and held at Mount Vernon, on I'uesday, the first day of June, in the year of our Lord one thousand eight hundred and sixty-nine, within and for the First Grand Division of the State of Illinois: Present-Breese, Chief Justice; Charles B. Lawrence, Justice; Pinkney H. Walker, Justice.

The People ex relatione South Park Commissioners, relators, v. The Judge of the Circuit Court of Cook County (E.S. Witliams)-Application for writ of mandamus.

[Opinion By Breese, Chinf Justice.]

This is an application by the South Park Commissioners for a mandamus to compel the judge of the circuit court of Cook 
comty to appoint lorthwith, on their petition, three disinterested freeholders of that county, commissioners to fix the compensation and assess the damages to be paid to the owners of the lands about to be taken by the relators for the South Park, under the provisions of the act of February 2t, 1869, entitled "An act to provide for the location and maintenance of a park for the towns of South Chicago, Hyde Park and Lake."

The only question presented in this record is the validity of the act cited. As that has been determined to be valid, and within the constitutional empetency of the legislature to chact. in the case of the same commisioners against Salomon, the deri of the county court, the mandamus, as prayed for, must be allowed. A peremptory mandamus will accordingly issue.

I, R. A. D. Wrubanks, clerk of the Supreme Court of Illinois, do hereby certify that the foregoing is a true copy of the final opinion of the said Supreme Court in the above entitled cause, of record in my office.

In testimony whereof I have set my hand and affixed the seal of the said Supreme Court, at Mount Vernon, this 18th day of Septemher, in the year of our Lord one thousand eight hundred and sixty-nine.

[SEAL.]

R. A. D. WILBANKS,

Clerk of the Supreme Court.

At a Supreme Court, begun and held at Mount Vernon, on Tuesday, the first day of June, in the year of our Lord one thousand eight hundred and sixty-nine, within and for the First Grand Division of the State of Illinois: Present-_. Sidney Breese, Chief Justice; Charles B. Lawrence, Justice; Pinkney H. Walker, Justice.

The People ex relatione South Part Commissioners v. E. S. Williams, Judge of the Cook County Circuit Court-Application for writ of mandamus.

[Opinion by Breese, Cinef Justice.]

This is an application by the South Park Commissioners for a mandamus to compel the judge of the circuit court of Cook county to appoint three freeholders of that county at park assess- 
ors, agreeably to the provisions of section $\%$ of the act of the general assembly of February 24, 1869, entitled "An act to provide for the location and maintenance of a park for the towns of South Chicago, Hyde Park and Lake."

The seventh section of the act to which reference is made is as follows:

SEc. $\%$ As soon as the amoint required for the condemmation of the grounds selected for said park shall have been ascertained by said commissioners, with reasonable certainty, they shall apply to the judge of the circuit court of Cook county for the appointment of three freeholders of the county of Cook as park assessors. The commissioners shall gire notice in one or more of the daily newspapers published in the city of Chicago of the time when such application will be made; and all parties interested may appear and be heard by the said judge touching such appointment. At the time fixed for such an application, the court, after hearing such persons as shall desire to be heard touching such appointment, shall nominate and appoint three assessors for the purposes provided in this act. The said assessors shall proceed to assess the amount so ascertained upon property in the towns of South Chicago, Hyde Park and Lake, in Cook county, deemed benefited by reason of the improvement oceasioned by the location of said park, as near as may be, in proportion to the benefits resulting thereto: Provided, That the aggregate of said benefits is equal to or greater than the amount of said damages; and in case the aggregate of the benefits is less than the damages, then the balance of the damages over the benefits shall be paid from the fund provided for in seetion eight of this act. Upon entering on the duties of their office, the said assessors shall make oath before the clerk of the said circuit court faithfully and impartially to discharge the duties of their oftice. They shall give at least ten days' notice in one of the said daily papers of the time and place of their meeting for the purpose of making said assessment, and may adjourn such meeting from time to time until the same shall be completed. In making the said assessment the said assessors shall estimate the values of the several lots, blocks or parcels of land deemed benefited by them, as aforesaid, and shall include the same, together with the 
amount assessed as benefits, in the assessment roll. All parties interested may appear before said assessors, and may be heard touching any matter connected with the assessment. When the same shall be completed, it shall be signed by the assessors, and returned to the said circuit court, and shall be filed by the clerk thereof. The assessors shall thereupon give at least ten days' notice in one of the said daily papers of the filing of said assessment roll, and that they will, on a day therein named, apply to the said circuit court for confirmation of the same, which said notice shall be published at least ten days before the time fixecl for such application. Said circuit court shall have power to revise, correct, amend or confirm said assessment in the whole or in part, and may make or order a new assessment in whole or in part, and the same revise and confirm upon like notice. All parties interested may appear before said circuit court, either in person or by attorney, when such application shall be made, and may object to said assessment, either in whole or in part, provided all objections shall be in writing, and shall be filed at least three days before the time fixed for the application, and shall specify the lot, block or parcels of land on behalf of which objection is made. After the confirmation of said assessment, the clerk of said circuit court shall file a copy thereof, under the seal of the said court, with the clerk of the county court of Cook county, and such assessment shall be a lien upon the several lots, blocks or parcels of land assessed for benefits as aforesaid. 'Ten per cent. of the amount so ascertained shall be due and payable annually, and the clerk of said Cook county court shall include in the general tax warrants for each year, until the whole sum shall be paid, for the collection of State and county taxes in said towns of South Chicago, Hyde Park and Lake, ten per cent. of the said assessments, in an appropriate column, to be termed "South Park Ascesment," with the amount to he collected opposite the several lots, blocks or parcels of land assessed as aforesaid; and like proceedings in all respects shall be had for enforcing the collection of the same as is now provided by law for the collection of State and county taxes. The money collected under the provision of this section shall be paid to the treasurer of Cook county, for which he and his sureties shall be respon- 
sible, as fully an for any other moneys received by him as treasurer of Cook county, and to be held by him in the same manner, and be subject to the same control and direction, as provided in this act for other moneys belonging to saicl corporation; and the treasurer of Cook county shall be entitled to receive one-half of one per cent., and no more, of said moneys, as a full compensation for receiving and disbursing the same."

The judge of the circuit court refused to act upon the petition to appoint the park assessors, until this court should express an opinion that the act referred to is so far valid that park assessors ought to be appointed by him, and until it is determined that the petitioners have ascertained the amount for the required condemnation of the ground for the park, as required by that act.

These two questions are presented for our adjudication-the first and most important of which (the central question- the validity of the act of Feb. 2t) - was fully discussed, and its validity established, in case of the same Relators r. Salomon, clerk of the county court of Cook county.

'The other question is to be determined by the provisions of the act itself. By reference to that, none will be found specifying in what particular mode the park commissioners should ascertain the probable amount necessary to be raised to pay for the lands inclosed in the park; they must make a careful estimate, upon proper inquiry and examination-and that in adrance of the purchase or condemnation of the land wanted. They are sworn officers, and we know of no guide but their own jurlgment as to the amount which may be required. It is not to be presumed such officers, sworn well and properly to discharge the duties of their office for the interest of the public, would, from any consideration, swerve from that oath, nor do we see any inducement for them to do so.

By the charter of most cities, special assessments are made in a like manner, and are levied in advance of the improvements contemplated. Proper officers are appointed to make such estimates. This law does not contemplate that the precise amount shall be estimated by the commissioners, but an approximation only, and there would seem to be no safer mode to effect this than through the judgment of sworn officers. 
The great objection to proceeding to appoint the assessors by the cireuit court, was evidently a doubt of the validity of the act itself, and as that is settled by the case of Salomon, supra, it is searcely necessary to enlarge upon minor and subordinate considerations.

On the point made by counsel that no means are prorided by the act for paying the compensation to be made to the property owners, it is a sufficient answer to say that, by the fifth section, proceedings to condemin the land wanted, and not granted or purchased, can be instituted, and carried on in the manner provided by the act of the general assembly of June 22, 1852, entitled "An act to amend the law condemning the right of way for the purpose of internal improvement," by which ample provision is made for the payment of condemnation money, before the land condemned can be appropriated.

If the damages assessed are not paid, the park commissioners cannot occupy the land, for it is the well-established doctrine of this court that in no other mode can an owner be deprived of his land through the exercise of the power of eminent domain. (Shute v. Chicago and Milwaukee Railroad Company, $26 \mathrm{Ill}$. 435.) It has been held by this court that benefits may be the compensation contemplated by the constitution (State v. Evans, 2 Scam., 208, and subsequent cases), thus paying for the land by the benefits conferred upon the owner's by the contemplated improvement. However unreasonable and unjust this may seem to be, it is the law of this court.

A peremptory mandamus will issue according to the prayer of the petition.

I, R. A. D. Wilbanks, clerk of the Supreme Court of Illinois, do hereby certify that the foregoing is a true copy of the final opinion of the said Supreme Court in the above entitled cause, of record in my office.

In testimony whereof I have set my hand and affixed the seal of the said Supreme Court, at Mount Vernon, this 18th day of September, in the year of our Lord one thousand eight humdred and sixty-nine.

[SEAL.]

R. A. D. WILBANKS,

Clerk of the Supreme Court. 
United States Suprene Coulit.

J. IV. Nesmiten, et al. $v$. 'T. C. SHeldon, et al.

In the supreme Court of the United States-

TANeY, Chief Justice.

Vol. 7 Howard Reports, page 416.

The following opinion was delivered by the court:

"It is the established doctrine of this court, that it will adopt "and follow the decisions of the State courts in the construction "of their own constitution and statutes, when that construction "has been settled by the highest judicial tribunal."

"After the decision above mentioned, therefore, the question "certified cammot be considered as open for argument in this "court."

\section{Suplene Court of Illinois.}

AMANDA S. COOK vs. THE SOUTH PARK COMLIISSIONERS.

This was an appeal from the circuit court of Cook county, by Mrs. Amanda S. Cook, from an award of commissioners appointed by that court, on the petition of the South Park Commissioners, in a proceeding for the condemnation, for park purposes, of certain real estate belonging to her. 'The proceedings were had under an act of the general assembly of February 24 th, 1869. The first sections provided for the organization of the Board of South Park Commissioners, which, by the terms of the act, became a corporate body. The fourth and second sections provide that "the said commissioners, by this act, are "authorized and empowered to, and they shall, within ninety "days after their organization as aforesaid, or as soon thereafter "as practicable, select the following described lands situated in "the towns of South Chicago, Hyde Park, and Lake, in Cook "county, Illinois, to wit, (describing the lands), which said "lands and premises, when acquired as provided by this act, "shall be held, managed," \&c. 
The fifth section provides that in case of disagreement, condemmation mar proceed under the right of way act of June "senth. $185 \%$.

The sixth section provides that, "when the title to the land "selected for such park as herein provided, shall have been "acquired by said commissioners," \&e., they shall acknowledge and record a plat.

Section eighteen provided for a popular election in the three towns named, and that the act should take effect upon a majority vote in the affirmative-not otherwise.

In estimating the value of lands taken, and the amount of damages, the benefits were also to be estimated.

On September 8th, 18\%0, the commissioners appointed to make the assessment, filed their report, estimating the compensation to be paid at $\$ 90,000$.

From this award Mrs. Cook appealed tc the circuit court, in which she had, January $16,18 \% 1$, judgment for $\$ 114,34 \% .18$, as the total value including interest.

Both parties took exception to the rulings and judgment of the court, and respectirely appealed to the Supreme Court.

On the trial below, it was stipulated that Mrs. Cook was at the date of the passage of the law, and had been ever since the owner of the premises in fee.

The statement of the testimony offered upon the trial, and the rulings of the court upon instructions asked by the parties, are embodied in the opinion of the court.

Messrs. Scammon, McCagg \& Fuller, for appellant.

Messrs. Beckwith, Ayer \& Kales, for appellees.

Mr. Justice Thonnton delivered the opinion of the court.

The law which authorized the commissioners to acquire lands to be held and controlled for a public park, described the lands to be selected. In determining the compensation to be paid to the owner of the lands taken, the chief question is, at what time shall their value be estimated?

In behalf of the commissioners, it is assumed that the proper time was when the law became operative by ratification by the voters; that then the property was irrevocably appropriated for public use; the owners were then divested of the beneficial en- 
joyment of it; deprived of all right to convey or improve it; and that nothing remained to be done but to ascertain and pay the compensation.

The instructions given upon the trial assume that the land was taken when the law went into operation, without any act on the part of the corporate authorities, to condemn it, or acquire it in any other manner, and that it was deroted to public nse by the enactment.

On the part of the appellant, it is contended, that the legislature cannot transfer the property of one man to another; cannot donate it to public use by its own mere declaration.

The constitution provides that "no freeman shall be * * * "in any manner deprived of his life, liberty, or property, but "by the judgment of his peers, or the law of the land."

Mr. Webster, in his argument in the Dartmouth College case, las given a very correct definition of the phrase, "the law of the "land," when he said: "By the law of the land, is most clearly "intended the general law which hears before it condemns, which "proceeds upon inquiry, and renders judgment only after trial. "The meaning is that every citizen shall hold his life, liberty, "property and immunities under the protection of the general "rules which govern society.

"Everything which may pass under the form of an enactment, "is not the law of the land."

This section of the constitution had reference only to the taking of the property of one man, and giving it to another. This is not within the scope of legislative authority, either with or without compensation. The citizen can only be deprived of his property, and the title transferred to another, by a fair trial and adjudication, according to the course of the common law. There can be no forced divestiture, except by judgment of law, when it is not taken for public use; the legislature cannot exercise judicial power, and therefore, mere legislation will not accomplish the transfer. Newland r. Marsh, 19 Ill., 376; Taylor v. Porter, 4 Hill., 140 ; Roys v. Prior, 14 Ill., 171.

The act in question does not undertake to deprive one person of property, for the purpose of vesting it in another. It merely empowers the commissioners to select certain described lands, 
and then recites "which said lands and premises when acquired "by said commissioners as provided by this act, shall be held, "managed and controlled *** as a public park; for the "recreation, health, and benefit of the public, and free to all "persons forever."

'The following section provides that if the commissioners cannot agree with the owners of the real estate, "selected as afore"said," they may proceed to procure its condemnation in the manner prescribed in the act concerning right of way, alplproved June 22d, 1852.

These provisions cannot properly be construed as an irrevocable appropriation of the land, an absolute divestiture of the title, a positive prohibition upon any alienation or improvement. a change of the estate from ownership in fee, to a mere tenancy at will. This would be a dangerous and unwarranted exercise of power by the legislature.

The commissioners were authorized to "select." The term implies choice. To choose, signifies to take one thing rather than another. When we select, we choose. It is true that other lands than those designated, could not be taken, because it would have been in excess of the power, yet the commissioners might have refused to select. The law conferred an authority to be exercised, but not to be exereised at all hazards, and without regard to results.

If the owners had insisted upon a most exorbitant price, and the probaloilities were against a fair price by condemnation, the commissioners should be permitted to decline the purchase. The legislature certainly never intended to force the selection without regard to consequences.

The words, too "when acquired as provided by this act," must have some meaning in determining the legislative intent. To acquire, expresses progressive and permanent action. It would be a solecism, to say that a man must acquire an estate or a title, when the estate or title was complete in him.

The lands were to be held as a public park, when acquired as provided. If no agreement could be made between the commissioners and owners, then the lands were acquired by condemnation. 
The several provisions of the law under which the condemnation must be procured, are antagonistic to the position that the land was taken by force of the South Park act.

Upon the filing of the petition, and notice given, commissioners are to be appointed. They must hear the allegations and testimony of the partics interested, and then fix the compensation to be paid to the owners of "lands to be taken," for the purposes specified in the act. They must view and inspect the premises. It would be a farce to inspect lands taken, and appropriated for more than one year prior to their appointment.

Again, it is provided that the "right and title" to the land required shall rest in the corporation, upon the paryment of the compensation, and that the judgment shall be so entered, "with "the right to enter upon, use, and apply" the land. Scates" Comp., 483, 485.

The language and plain intent of the statute are, that no right to the land shall inure to the corporation, until payment of the compensation. It may be unnecessary to decide whether payment must precede any use or possession of the land; but the constitution, without reference to the law, requires, in the taking of property for public use, by State or municipality, that there must be some adequate source of compensation, and that the owner of the property shall be secure in the payment. He cannot merely be referred to a corporation of doubtful responsibility, and a judgment which may prove to be worthless.

But, this question as to the right of the commissioners to take possession of the land in controversy, was determined in the case of The People v. Williams, 51 Ill., 63. In that case, where the same laws were under consideration, it was said that the park commissioners ammot neculyy the land until the damages assessed are paid, and that in no other mode can an owner be deprived of his land through the exereise of the power of eminent domain.

In regard to similar laws, it has always been the doctrine of this court, that the damages must be paid before possession of the land can be taken, or any right to it acquired. Chicago $d$ Mitwaukee Railroad Co. v. Bull, 20 Ill., 218; Johnson v. Joliet d: Chicago Raitroad Co., 23 Ill., 203; Shute v. Chicago \& Miturankece Raitroad Co., 26 I1l., 436. 
The inhibition in the constitution is, "nor shall any man's "property be taken, or applied to public use, without the con"sent of his representatives in the general assembly, nor without "inst compensation being made to him."

The counsel for appellees insist that the word "taken," is not to be understood in its physical sense, because, under our statute the land cannot be actually entered upon, and applied to public use, until after the compensation lias been ascertained and paid. The reason given is certainly peculiar. It is, that the constitution does not mean an actual taking, for the statute prohibits an actual entry until the payment of the compensation. Eren if the statute were in conflict with the constitution, the latter must control as the supreme law. But it is not. The statute provides that the title to the land, and the right to enter upon and use it, must follow the payment of the damages awarded.

The law which created the park commissioners, by virtue of which alone they are constituted a corporate authority, refers to and adopts the law of June 22nd, 1852, as the one which must govern the commissioners in acquiring title to the land and the possession of it.

This latter law requires that persons who may be appointed "commissioners to assess damages, shall inspect "the lands to be "taken," not the lands already taken.

In the construction of a law, we must consider every part, ponder the effect of every word, to ascertain the intent of the legislature. The law under consideration, eridently construed the words, "taken or applied to public use," in a physical sense. When it required that compensation must precede any possession, use or application of the land to the purpose intended, what was meant? The taking of the land-the appropriation of it-prior to the performance of the prerequisite of the statute, would be utterly inconsistent with the obvious meaning of the words of the law. If the land cannot be entered upon or used before payment of the compensation, it cannot with any propriety of language, or with reference to the common signification of the term, be said to be taken before payment.

This would be a distortion of the sense of the word. It cannot, literally or metaphorically, hare such meaning in connec- 
tion with the statute. We have been referred to authorities in Massachusetts, and some in other States, in which the question as to the time when property shall be deemed to be taken, is discussed. These decisions were made with reference to the peculiar phraseology of statutes which differ somewhat from our ow?.

The statute of Massachusetts required that railroad corporations should file a certificate of the location of the road within a limited period. In the construction given to the statute, there is some slight diserepaney.

In some cases it has been decided that the filing of the location should be considered the taking of the land, and conclusive upon the corporation and land owner. Boston di Providence Rifilroad Co. r. Midland liailroad Co., 1 Gray, 340; IIagan r. Boston d. Waine Railroad Co., 2 Gray, $5 \%$.

In other cases it was held that, as the company might never file a location, the question whether the filing was the only act of taking was a difficult one; and that the filing of a location might be regarded as prima facie, a taking in the absence of other proofs. Davison v. Boston \& Maine Railroad Co., 3rd Cusl.., 91; Boynton. V. Peterboro \& Shirley Railroad Co., 4th Cush., $46 \%$.

These decisions to not aid us very much.

We think that the act for the location and maintenance of the park, and the act to condemn lands for any public work, when considered together, do not bear the construction that the land of appellant was taken by the former act. If such were the necessary construction, the law must be pronounced a violation of the constitution. The legislature has not the power by mere declaration of law, to set apart the land of the citizen, for the use of corporations and divest the owner of the right to sell and improve it. It cannot by arbitrary enactment, take property for public use, and limit the owners' right to recover compensation to the date of the law, when the property might greatly enhance in value between the passage of the law, and the time when proceedings to condemn are commenced.

We therefore think that the evidence excluded by the court should have been admitterl, and that the value of the land shonld 
be estimated at the date of condemnation. This would approximate more nearly to right and justice, and to the time when the land is actually taken, as contemplated by the law.

The judgment was entered in proper form, but it is in direct conflict with instructions given by the court. 'The court instructed the jury that the owner of the land was liable for the rental value of the land for more than one year before the commencement of proceedings to condernn. The corporation had no right to enter upon or use the premises until the compensation was fixed and paid. There was neither right nor title in the corporation prior to filing the petition. 'The title was in the owner, as well as the right of occupancy.

Upon what principle of reason or law can the absolute owner of lands in possession be made chargeable with rent? The relation of landlord and tenant did not exist by any express agreement. Can it be implied? No one will assume that the commissioners had the legal title, and tenancy will never be implied under any one who has not the legal estate.

The appellant did not enter in subordination to the title of any other person, and never acknowledged any obligation to another. She was in possession as the owner in fee, and claiming adversely to all the world, and the proceedings for condemnation were an acknowledgment of her title. The only hypothesis which can be made is, that mere legislation divested her of title, and made her an involuntary tenant of the corporation. The doctrine is monstrous, and cannot be sustained.

Complaint is made of the refusal of the court to give certain instructions. The court did not err in refusing to give the eighth, ninth and tenth instructions for appellant.

The eighth and ninth are substantially, that if lands adjacent to the park generally increased in value in consequence of the prospect of establishing a public park, then the lands of the appellant must share in such increase. This does not fairly or necessarily follow. The adjacent lands would probably from their peculiar situation, derive a special benefit, and were subject to a special burden. The lands needed for the park must be purchased, and the park maintained by special assessments upon the adjacent lands. Their situation relatively was so dif- 
ferent that they were not a proper standard by which to judge the value of the lands taken for the park.

The tenth instructoin is clearly objectionable. It directed that if one class of lands was unsalable, and another class salable, the latter class would form the better criterion to ascertain the true value of the lands in controversy.

It was not proper that the court should assume as matter of law that one criterion was better than another. This would have been a usurpation of the functions of the jury. The relative situations of the lands was a subject for the consideration of the jury, and they. must determine its weight and its effect upon the value.

It seems to us that the first two paragraphs of the instruction given by the court upon its own motion, contains all the law which was necessary to aid the jury in determining the value of the lands.

We think there was no error in refusing to allow interest on the amount of the rerdict, intermediate its finding and return, and the rendition of the judgment of the court thereon.

Appellant as well as the commissioners, made a motion to set aside the verdict, and for a new trial. The amount might have been paid if appellant had interposed no delay. In such case it is not right that the party causing or contributing to the delay; should be allowed interest. Williams v. Smith, 2 Caines, 252; People v. Gaine, 1 Johns., 343.

At the time the court entered judgment upon the verdict of the jury, appellant insisted that the judgment should be absolute for the payment of the sum found. The judgment was entered in strict conformity to the statute. It could not have been in any different form. The court had no right to award an execution, for execution could not issue upon the judgment. Chicago and MIil. R. R. Co. v. Bull, 20 Ill., 218.

The only mode to coerce the payment of the judgment, would be by mandamus. By this proceeding the commissioners could be compelled to levy and collect taxes to be applied in discharge of the damages awarded.

But we are asked to decide whether the judgment will not by force and operation of law bear interest from the time of its rendition. 
When judgment has been entered upon the verdict, the rights of the parties are fully determined, if no appeal be taken, or writ of error be prosecuted. The absolute title to the land, and the right to enter upon and use it, only await the payment of the compensation which has been fixed. The amount to be paid is as fully and formally ascertained as is done by an ordinary judgment. The court had authority to render it. It only wanted one of the requisites of a common judgment-the award of an execution.

Though no execution could be ordered, the judgment was the conclusion of the law upon the facts found by the jury. The allowance of a claim against an estate is a judgment. Judgments may be rendered against an executor or administrator for the debt of the deceased, and no execution can issue in either case, but they bear interest. We think that interest should be allowed upon judgments when final, in proceedings of this character. They are within the spirit, if not terms, of the statute. which allows interest upon all judgments recorered.

Counsel for appellees contend that the court erred in refusing to permit proof of the price paid for other lands in the park lines, and contiguous to the lands in controversy.

No cross error has been assigned upon this refusal; no argument submitted on the part of appellant upon the question presented; and we cannot regard the relevaney of this testimony raised by the record. It would be unjust to appellant, to decide the question without a hearing from her.

For the reasons given the judgment is reversed, and the cause remanded.

Judgment reversed. 


\section{GENERAL PARK ACT}

AN ACI to enable the corporate authorities of two or more towns, for park purposes, to issue bonds in renewal of bonds heretofore issued by them, and to provide for the payment of the same; to make, revise and collect a special assessment on contiguous property, for benefits by reas on of the location of parks and boulevards, and to make necessary changes in their location. [Approved June 16, 18\%1. In force July 1, 18\%1.]

Section 1. Be it cnacted by the People of the State of Jllinois, represented in the General Assembly, 'That persons who have been appointed or otherwise selected as commissioners or officers, under and in pursuance of any act or acts of the general assembly of this state, which has or have been submitted to the legal voters of one or more towns, and by them respectively adopted, for the purpose of locating, establishing, inclosing, improving or maintaining any public park, boulevard, drive-way, highway or other public work or improvement, are declared to be corporate authorities of such towns for the purposes named in such act or acts, whether such persons are authorized to discharge the duties imposed upon them as a corporation or otherwise.

SEc. 2. Corporate authorities of towns who have been authorized by law to issue bonds for the purpose of establishing, inclosing, improving or maintaining any public park, boulevard, drive-way, highway or other public work or improvement in such towns, may issue new bonds, payable not more than twenty years from the date thereof, and the same exchange for bonds issued by such corporate authorities for the same purpose. The said corporate authorities may purchase any bonds issued by them, at any rate not exceeding the par value thereof, and issue, in lieu of the same, bonds payable as aforesaid. Such new bonds shall be issued under the seal of said corporate authori- 
ties, if they have one, and shall be signed by them and comtersigned by their secretary, if they have one, and bear interest not exceeding seven per cent. per annum, payable semi-annually, and the principal and interest may be made payable at any place or places within or without this state. The said bonds shall also contain a provision securing to said corporate authorities the right, if the said bonds or a sufficient number of them cannot be purchased at not exceeding one per cent. above the par value thereof, for the yearly sinking lumb lereinaltere provided, to pay and retire, at the end of each year after the date of said bonds, or so soon thereafter as due notice shall have been given, such number of the same as may be necessary for that purpose, to be selected by lot by said corporate authorities, in the manner hereinafter provided. It shall be the duty of said corporate authorities to keep an accurate register of all bonds issued by them, showing the number, date and amount of each bond, and said register shall at all times he open to the insuection of the puhlic. The public park, boulevard, drive-way, highway or other public work or improvement, on account of which said bonds may be issued, shall be irrevocably pledged for the payment of the principal and interest thereof, and the towns in which such public park, boulevard, drive-way, highway or other public work or improvement, are in whole or in part situated, shall also be irrevocably bound for the payment of the same. Bonds issued under this act may be exchanged as aforesaid or sold by said corporate authorities for such prices as they may deem expedient; but the proceeds of bonds sold shall only be used for the payment or purchate of outstanding honds which ammot he exchanged. The bonds received in exchange or purchased as aforesaid shall be canceled, whereof an entry shall be mate upon the hond register of said corporate authorities showing the date, number and amount of each bond canceled, and no bonds shall be issued under this act exceeding the amount already issued, nor contrary to the provisions of section 12, article 9 of the constitution of this state, nor until provision is made by law for the collection of a direct annual tax sufficient to pay the interest on such bonds as it falls due, and also to pay and discharge the principal thereof on or lefore the time when the same 
shall become due. And whenever any provision has been made by any act or acts of the general assembly of this state, for the assessment and collection of an annual tax, in order to pay the interest on bonds issued by said corporate authorities, the provisions of said act or acts are hereby continued and extended so as to require the assessment and collection of said annual tax, not only for the purposes of said act or acts named, but for the payment of the interest on any bonds which may be issued under this act, and to provide for the anmual payment of a part of the principal thereof. Officers collecting said annual tax are required, at the end of each month, to pay to said corporate authorities so much of said tax as has been collected; and for collecting and paying over of said annual tax no compensation shall be allowed, except the salary allowed by law to the collector thereof. And if, for any cause, any portion of said annual tax required to be assessed and collected as aforesaid shall, for any one or more years, fail to be collected, the said corporate authorities are required to add such deficiency or deficiencies to the amount required to be assessed in the succeeding year or years; and the amount of such deficiency or deficiencies shall be by the proper officers assessed and collected, in the same manner as said annual tax, and as a part thereof. The said corporate authorities are required to cause said tax, and any deficiencies occurring as aforesaid, to be asssessed and collected as required by law, and to apply sufficient thereof, from time to time, to pay the interest upon said bonds issued, and which may be issued as the said interest shall fall due. And at the end of the year after the date of any bonds issued under this act, and of every year thereafter, the said corporate authorities shall, from the proceeds of said annual tax, set apart not less than three and one-fourth per cent. of the whole amount of bonds issued under this act, and a sum equal to the annual interest on said sum, at the rate of interest borne by said bonds, which sums shall be applied by said corporate authorities in the purchase of bonds issued by them, if the same can be obtained at not exceeding one per cent. above the par value thereof; and if the said corporate authorities cannot obtain said bonds, or sufficient of them, to absorb said fund at that price, then from the outstand- 
ing bonds isued under this act. and not therefore selectert. shall be selected by lot so many thereof as may be required to absorb the funds so set apart for a sinking fund. The said selection shall be made by said corporate authorities at the end of each successive year after the date of said bonds, or within one month thereafter, in the presence of one of the judges of the circuit court of said county, who, with said corporate authorities, shall make and sign duplicate certificates of the result thereof, one of which shall be filed in the office of said corporate authorities and the other in the office of the county clerk of said county. Notice of said selection, and of the numbers of the bonds so selected, shall be forthwith given by said corporate authorities in one or more newspapers published in said county and in the city of New York, and if the owners of said bonds shall be registered, notice to such owners shall also be given by letter mailed to the address of such owner at his place of residence if known, or shown upon said register. The interest on bonds selected by lot, as aforesaid, shall cease from and after the time when the semi-annual interest on the same shall fall due, next after said selection is made; and from the sums so set apart for a sinking fund shall be paid the bonds so selected by lot, as aforesaid, with interest until payment or until the same shall cease as aforesaid. The funds so set apart for a sinking fund shall not be used for any purpose other than purchasing bonds to be canceled, and paying bonds selected as aforesaid for the same purpose. The bonds so selected, when paid, and the bonds purchased, shall be canceled, a certificate whereof, stating the numbers, date and amount of said canceled bonds, shall, from time to time, be made by said corporate authorities, and filed in the office of the county clerk of said county.

SEC. 3. Corporate authorities of one or more torns, who have been authorized to make, establish or maintain any local improvement, in whole or in part, by special assessment or special taxation of contiguous property, or otherwise, may estimate, as near as may be, the probable cost of the lands taken, or to be taken or purchased for such improrement, or rerise, enlarge and correct any estimate theretofore made, and make a new one of the same, and of the expenses of obtaining said lands, to- 
gether with the cost of making and collecting a special assessment to pay the cost of said lands and expenses, and shall apportion the estimated cost of said lands, expenses, and the cost of assessment as aforesaid, upon lands situated in said towns, by said corporate authorities deemed benefited by reason of said local improrement, as near as may be, in proportion to the benefits resulting thereto. And if said corporate authorities shall not deem the lands in said towns benefited to the full extent of the estimated cost of the lands taken, or to be taken or purchased as aforesaid, and the costs and expenses aforesaid, then the said corporate authorities shall in like manner apportion so mueh thereof as they shall deem the lands in said towns benefited. The said corporate authorities shall give at least ten days' notice, in one or more newspapers published in the county in which such towns are situated, of the time and place of their meeting for the purpose of making said assessment, and may adjourn such meeting from time to time until the same shall be completed. In making the said assessment, the lots, blocks and parcels of land deemed benefited as aforesaid, shall be assessed according to the descriptions and divisions thereof appearing of record in said county, on the day of the said first meeting, for the purpoes of making the said assessment, but no error in the description or division of any lot, block or parcel of land, in making said assessment, shall vitiate the same, provided the premises are described with substantial accuracy. The said corporate authorities shall estimate the value of the several lots, blocks or parcels of land deemed by them benefited as aforesaid, and shall include the same, together with the amount assessed for benefits, in an assessment book or roll. All parties interested may appear before said corporate authorities, and may be heard touching any matter connected with the assessment. When the same shall be completed, it shall be signed by the said corporate authorities, or by a majority thereof, and returned to the circuit court of the county in which such towns are situated, and filed with the clerk of said court, whereupon the said corporate authorities shall give at least ten days' notice of the filing of said assessment roll, and that they will, on a day named, apply to the said circuit court for confirmation of the same. 
Said notice shall be signed by said corporate authorities, or by a majority of them, and shall state the general nature of the improvement for which said assessment was made, and the towns, township, range and section in which the same is situated, without further description of its locality, and shall also state when the said assessment was filed in said court, and the day when the said corporate authorities will apply to said court for confirmation of the same; but said notice need not contain a description of the lots, blocks or parcels of land assessed, nor the amount assessed upon them, or any of them, nor mention any particular law or laws of this state under which said assessment was made; which said notice shall be published in one or more newspapers published in the county in which said towns are situated, at least ten days before the time therein named for such application. When it shall appear to said court that proper notice has been given, it shall have power to hear, adjudge and determine the matter of said application and all matters connected therewith. Any person interested in any lot, block or parcel of land assessed, may appear therein, in person or by attorney, and object to said assessment: Provided, all objections shall be in writing, and be filed in said court at least three days before the time fixed for said application, and shall specify the lots, blocks or parcels of land wherein the said person objecting is interested, in respect whereof objections are made, and the grounds thereof. Said court shall have power to revise, correct, amend and confirm the said assessment in whole or in part, and may without further notice or order make a new assessment in whole or in part, and the same confirm, or may order a new assessment to be made in whole or in part, and the same may revise, correct, amend and confirm upon like notice as aforesaid, or upon such notice as it may prescribe; but no order to make a new assessment in part, shall hinder or delay the confirmation of the residue or the collection thereof. From and after the time the amount of any assessment shall be ascertained and comfirmed by waid court, as to any lot, block or parcel of land so assessed, the amount thereof shall be a lien thereon, and may be paid at any time. The said court shall divide the amount of said asseswent into installments, aud fix the amount 
of the first installment, but the first installment shall not exceed twenty-five (25) per cent. of said assessment. The portion of said assessment, after deducting therefrom said first installment, shall be divided by the court into seren equal installments, which said installments shall be payable annually thereafter, and the court shall fix the time on or before which each of said installments shall severally be paid. All installments shall bear interest at the rate of seven per cent. per annum, from the time on or before which the payment of the first one is to be made. The said corporate authorities or their officer, from time to time, duly authorized by them, and to be mentioned in some order or orders of said court which it may from time to time make, shall have full power and authority to collect such assessments from the owners of such lands, and to give all proper receipts and discharges therefor. The orders of said court shall be conclusive evidence of the regularity of all previous proceedings necessary to the validity thereof, and of all matters and things therein recited as having been heard and adjudged by said court. It shall be the duty of the clerk of said conrt to enter in said assessment book or books, or upon said assessment roll, all revisions, corrections and amendments of such assessment, and all new assessments made by the court, and all revisions, corrections and amendments of the same, and all orders for new assessments, and all new assessments made in pursuance of such order, and all revisions, corrections and amendments of the same, together with all orders of the court in said proceedings. The said corporate authorities are required to furnish to the clerk of said court a duplicate copy of said assessment book and books, or roll, wherein shall be entered from time to time, by said corporate authorities, the several matters and things entered in said original assessment book or books, or upon said original assessment roll, which duplicate and the entries thereon shall from time to time, as they are made, be certified by the clerk of said court under the seal thereof, as a true copy of the original; and such duplicate copy of the assessment book and books, or roll, certified as aforesaid, shall be sufficient authority to said corporate authorities, or to their officer designated therein, to collect any assessment therein confirmed as 
aforesaid, and to receipt for and discharge the same. It shall be the duty of the officer having the custody of said original assessment book or books, or roll, to enter thereon, from such receipt or discharge, the fact of such payment, which entry shall be evidence of the same. After the proceedings in the said circuit court shall be finally concluded and terminated, it shall be the duty of the clerk thereof to deposit said original assessment book and books; or roll, and all proceedings relative to the same, duly entered as aforesaid and properly certified, with the county clerk of the county in which such towns are situated. In case said assessments or any part thereof, so confirmed as aforesaid, shall not be paid at the time or times fixed therefor by the orders of said cirenit court, it shall be the duty of the corporate authorities to return to the county treasurer, or to some general officer of said county laving authority to receive state and county taxes, a list of the lots, blocks and parcels of land so assessed upon which said assessment shall remain unpaid, and the amount umpaid upon each lot, block or parcel of land; and from and after the return of such delinquent list the said county treasurer, or other general officer of said county having authority to receive state and county taxes, as well as said corporate authorities, or their officer, shall have authority to receive any of said unpaid assessments, and to give all proper receipts and discharges therefor. It shall also be the duty of said corporate authorities to make and certify to the county court in which such towns are situated, a return, therein designating the said delinquent lands and the due and unpaid assessments against the same, and thereupon the said corporate authorities shall give notice, by publication in one or more of said newspapers, that they will, on a day in said notice named, apply to said county court for judgment against all delinquent lots, blocks or parcels of land upon which said assessment, or any part thereof, shall be unpaid. Such notice may be general, but must contain a description of the lots, blocks or parcels of land, and the names of parties interested, if known, and the amount due and unpaid, which notice shall be published in one or more of said newspapers at least ten days before the time fixed for making said application, and the said application may be made 
on the day named, or any day of the same term, by the permission of said court. The said corporate authorities and the said county treasurer, or other general officer of said county to whom said delinquent list shall have been returned, shall respectively report to said court the respective lots, blocks and parcels of land upon which said assessment has been paid to them respectively after the return of said delinquent lists as aforesaid. And thereupon said proceedings, orders and judgments shall be had, as nearly als may be, as in cases of delinquent lands whereof judgment is prayed for the non-payment of state and county taxes, and the said judgments shall be conclusive of the regularity of all matters necessary to the validity thereof, excepting the giving of said notice of the application for judgment. After said notice for application for judgment shall have been published, the cost of publication shall be added to the assessment, as in the case of state and county taxes. After judgment shall have been rendered, the same shall be executed in the same manner, as nearly as may be, as is or may be provided by law for executing judgments for state and county taxes, but no judgment or sale of any lot, block or parcel of land so assessed, for any one installment of said assessment, shall discharge the premises from any subsequent installment of the assessment; and proceedings for the non-payment of subsequent installments may be had in the same manner as if no default had been made in previous ones. All moneys collected by said treasurer or other general officer of said county, and all moneys realized from the sales of said lands upon judgments as aforesaid, shall at once be paid over to said corporate authorities, who shall execute a proper receipt therefor. The said county treasurer, or other general officer, shall not be entitled to any compensation for receiving and disbursing of moneys by him under this act, or for services rendered by him as herein required, except the salary allowed him by law. Any and all moneys collected or obtained upon or out of said assessments may be applied by the said corporate authorities to and for any of the uses and purposes named or intended by the act or acts under which they are organized. And if the proceeds of said assessments shall amount to a greater sum 
than the cost of the lands, expenses and cost of assessment and collection as aforesaid, the overplus shall be applied by said corporate authorities towards making the improvement which they are authorized to make: Provided, that such excess shall not exceed the sum of $\$ 25,000$. If it exceeds that sum, then and in that case it shall be refunded pro rala to the parties paying such assessment. Any and all such corporate authorities, as aforesaid, may avail themselves of the provisions and privileges of this act, notwithstanding any provisions in the several acts creating them.

SEc. 4. Corporate authorities of towns having the control or supervision of any public park, boulevard, driveway or highway, which has been located in pursuance of a vote of the people of such towns, desiring to alter or change the location of the same or any part thereof, or of any of the boundary lines of the same, may, by petition in writing, apply to the circuit court of the county in which such towns are situated, for leave to make such alteration or change. Notice of such application shall be given by said corporate authorities in some newspaper published in said county, at least ten days before the day named therein when said application will be made. All persons interested may appear before said circuit court, either in person or by attorney, when said application shall be made, and object to the granting thereof. After hearing all persons interested, if said court shall deem the granting of said application to be for the public interest, it shall make an order granting to such corporate authorities leave to make such alteration or change, or such part thereof, as it may deem for the public good, and granting power to acquire by purchase, or under any law of this state for acquiring lands for publice use, such additional lands as such change or alteration may, in the judgment of said court, rencler necessary, and if by reason of any such change or alteration any parcel of land shall no longer be deemed necessary or useful for the purposes of said park, boulevard, driveway or highway, the said court may direct the same to be sold and conveyed for the use of said park, upon such terms and conditions as it may think proper. Damages sustained by any person injuriously affected by reason of any such change or alteration, shall be 
ascertained and paid in the same manner as in other cases of the exercise of the right of eminent domain. The said corporate authorities shall make, acknowledge and file for record in the office of the recorder of deeds for such county, a map showing any change or alteration made under any order of court as aforesaid: Provided, that no application shall be made under or by virtue of this section, after the first day of July, in the year of our Lord $18 \% 2$, nor shall any change be made affecting the general location of any such park after said date.

Src. 5. When any town, towns or corporation is subject to taxation or special assessment for the improvement of any park or parks approached or connected by boulerard or boulevards, the money so raised by taxation or special assessment remaining unexpended, after defraying the expense for improving the boulevard or boulevards to said park or parks, shall be expended upon the parks (if more than one) in said town, towns or corporation, pro rata, according to the number of acres in each, unless already sufficiently improved; and it is hereby made the duty of the board of commissioners of any park or parks to cause the money to be so expended. 'The commissioners having in charge the maintenance and improvement of any public park or parks, boulevard, driveway, highway or other public improvement, under or by virtue of this act, shall, on the first day of December, in the year of our Lord 18\%1, and annually thereafter, submit to the board of county commissioners or board of supervisors in the county in which the same may be located, a written or printed report of all their acts and doings in relation to the parks and other improvements under their supervision or control.

SEc. 6. All laws and acts ineonsistent with this act are hereby repealed. 


\section{EMINENT DOMAIN}

AN ACT to provide for the exercise of the right of eminent domain. [Approved April 10, 18\%2. In force July 1, 18\%2. R. S. $18 \% 5$, p. 475 .]

Srotion 1. Be it cnacted by the People of the State of Lilinois, represented in the General Assembly, That private property shall not be taken or damaged for public use, without just compensation; and that in all cases in which compensation is not made by the state in its corporate capacity, such compensation shall be ascertained by a jury, as hereinafter prescribed. [See Const., art. 2, Sec. 13, p. 60 ; art. 11, Sec. 14, p. 79.]

SEC. 2. That in all eases where the right to take private property for public use, without the owner's consent, or the right to construct or maintain any public road, railroad, plankroad, turnpike road, eanal or other public work or improvement, or which may damage property not actually taken, has been heretofore or shall hereafter be conferred by general law or special charter upon any corporate or municipal authority, public body, officer or agent, person, commissioner or corporation, and the compensation to be paid for or in respect of the property sought to be appropriated or damaged for the purposes above mentioned cannot be agreed upon by the parties interested, or in case the owner of the property is incapable of consenting, or his name or residence is unknown, or he is a non-resident of the state, it shall be lawful for the party authorized to take or damage the property so required, or to construct, operate and maintain any public road, railroad, plankroad, turnpike road, canal, or other public work or improvement, to apply to the judge of the circuit or county court, either in vaeation or term time, where the said property or any part thereof is situate, by filing with the clerk a petition, setting forth, by reference, his or their authority in the premises, the purpose for which said property is sought 
to be taken or damaged, a description of the property, the names of all persons interested therein as owners or otherwise, as appearing of record, if known, or if not known stating that fact, and praying such judge to cause the compensation to be paid to the owner to be assessed. If the proceedings seek to affect the property of persons under guardianship, the guardians, or conservators of persons having conservators, shall be made parties defendant, and if of married women their husbands shall also be made parties. Persons interested, whose names are unknown, may be made parties defendant by the description of the unknown owners; but in all such cases an affidavit shall be filed by or on behalf of the petitioner, setting forth that the names of steh persons are unknown. In cases where the property is sought to be taken or damaged by the state for the purpose of establishing, operating or maintaining any state house or state charitable or other state institutions or improvements, the petition shall be signed by the governor or such other person as he shall direct, or as shall be prorided by law.

SEc. 2. If such petition be presented to a judge in vacation. the judge shall note thereon the day of presentation, and shall also note thereon the day when he will hear the same, and shall order the issuance of summons to each resident defendant, and the publication of notice as to each non-resident defendant, and the clerk of the court shall at once issue the summons and give the notices accordingly.

SEC. t. Service of such summons and publication of such notice shall be made as in cases in chancery.

SEC. 5. Causes may be heard by such judges in vacation as well as in term time, but no cause shall be heard earlier than ten days after service upon defendant, or upon due publication against non-residents. Any number of separate parcels of property, situate in the same comnty, may be included in one petition, and the compensation for each shall be assessed separately, by the same or different juries, as the court or judge may direct. Amendments to the petition, or to any paper or record in the cause, may be permitted whenever necessary to a fair trial and final determination of the questions involved. Should it become necessary at any stage of the proceedings to bring a new 
party before the court or judge, the court or judge shall have the power to make such rule or order in relation thereto as may be deemed reasonable and proper; and shall also have power to make all necessary rules and orders for notice to parties of the pendency of the proceeding, and to issue all process necessary to the execution of orders and judgments as they may be entered.

SEC. 6. In cases fixed for hearing of petition in vacation, it shall be the duty of the clerk of the court in whose office the petition is filed, at the time of issuing summons or making publication, to write the names of each of sixty-four disinterested freeholders of the county on sixty-four slips of paper, and, in presence of two disinterested freeholders, cause to be selected from said sixty-four names twelve of said persons to serve as jurors-such selection to be made by lot and without choice or discrimination; and the said clerk shall thereupon issue venire, directed to the sheriff of his county, commanding him to summon the twelve persons so selected as jurors to appear at the court house in said county, at a time to be named in the venire.

SEC. \%. The petitioner, and every party interested in the ascertaining of compensation, shall have the same right of challenge of jurors as in other civil cases in the circuit courts. If the panel be not full by reason of non-attendance, or be exhausted by challenges, the judge hearing such petition shall designate by name the necessary number of persons, of proper qualification, and the clerk or justice shall issue another venire, returnable instanter, and until the jury be full.

SEC. 8. When the jury shall have been so selected, the court shall cause the following oath to be administered to said jury:

"You and each of you do solemnly swear that you will well and truly ascertain and report just compensation to the owner (and each owner) of the property which it is sought to take or damage in this case, and to each person therein interested, according to the facts in the case, as the same may be made to appear by the evidence, and that you will truly report such compensation so ascertained: so help you God."

SEC. 9. Said jury shall, at the request of either party, go upon the land sought to be taken or damaged, in person, and 
examine the same, and after hearing the proof offered make their report in writing, and the same shall be subject to amendment by the jury, under the direction of the court or the judge, as the case may be, so as to clearly set forth and show the compensation ascertained to each person thereto entitled, and the said rerdict shall thereupon be recorded: Provided, that no benefits or advantages which may accrue to lands or property affected shall be set off against or deducted from such compensation, in any case.

SEc. 10. The judge or court shall, upon such report, proceed to adjudge and make such order as to right and justice shall pertain, ordering that petitioner enter upon such property and the use of the same, upon payment of full compensation, as ascertained as aforesaid; and such order, with evidence of such payment, shall constitute complete justification of the taking of such property.

SEc. 11. Any person not made a party may become such by filing his cross petition, setting forth that he is the owner or has an interest in property, and which will be taken or damaged by the proposed work; and the rights of such last named petitioner shall thereupon be be fully considered and determined.

SEC. 12. In all cases, in either the circuit or county court, or before a circuit or county judge, an appeal shall lie to the supreme court.

SEC. 13. In cases in which compensation shall be ascertained as aforesaid, if the party in whose favor the same is ascertained shall appeal such proceding, the petitioner shall, notwithstanding, have the right to enter upon the use of the property upon entering into bond, with sufficient surety, payable to the party interested in such compensation, conditioned for the payment of such compensation as may be finally adjudged in the case and in case of appeal by petitioner, petitioner shall enter into like bond with approved surety. Said bonds shall be approved by the judge before whom such procceding shall be had, and executed and filed within such time as shall be fixed by saick judge.

SEc. 14. Payment of compensation adjudged may, in all 
cases, be made to the county treasurer, who shall, on demand, pay the same to the party thereto entitled, taking receipt therefor, or payment may be made to the party entitled, his, her or their conservator or guardian.

SEC. 15. The court or judge shall cause the verdict of the jury and the judgment of the court to be entered upon the records of said court.

SEc. 16. All laws and parts of laws in conflict with the provisions of this act are hereby repealed: Provided, that this act shall not be construed to repeal any law or part of law upon the same subject passed by this general assembly; but in all such cases this act shall be construed as providing a cumulative remedy.

\section{REVENEE LAIT APPLICABLE TO COLLECTION OF THE ASSESSMENT.}

SECTION 1\%8. When any special assessment made by any city, town or village, pursuant to its charter, or by any corporate authorities, commissioners or persons, pursuant to law, remain unpaid in whole or in part, return thereof shall be made to the county collector on or before the tenth day of March next after the same shall hare become payable, in like forms as returns are made for delinquent land tax. County collectors shall collect, account for, and pay over the same to the authorities or persons having authority to receive the same, in like manner as they are required to collect, account for and pay over taxes. The county collector may, upon return of delinquent special assessments to him, transfer the amounts thereof from such returns to the tax books in his hands, setting down therein, opposite the respective tracts, or lots, in proper columns to be prepared for that purpose, the amounts assessed against such tract or lot. [As amended by act approved May 3, 18\%3. See Sees. $2 \% 9,299$.

SEC. 179. When any special assessment is returned against property, the taxes upon which shall have been paid to the town 
or district collector, it shall be the duty of the county collector, to cause demand to be made for the payment of such special assessment, or a notice thereof to be sent by mail, or otherwise, to the owner, if his place of residence is known. The certificate of a collector that such demand was made, or notice given, shall be evidence thereof.

SEC. 180. On the application of any person to pay any tax or special assessment upon any real property, it shall be the duty of the county collector to make out to such person a receipt, in which shall be noted all taxes and assessments upon such property, returned to such collector and not previously paid.

SEC. 181. County collectors shall have the same power, and may proceed in the same mamner for the collection of any tax on real or personal property, as is or may be given to town or district collectors.

AN AC' in relation to the collection of taxes and special assessments. [Approved and in force May 2, 1873.]

Whereas, certain requirements of the general revenue law of this state, relating to the mode of advertising the list of delinquent taxes and special assessments, to making application for judgment thereon, and the manner of making the tax sale. are impracticable; and whereas, it is desirable to remove existing defeets as to the manner of collecting the taxes and special assessments ; therefore,

SECTION 1. Be it enacted by the People of the state of Illinois, represented in the General Assembly: When a return to the county collector has been made or shall hereafter be made of any real estate delinquent for any special assessment, or annual installment thereof, levied by any incorporated city, town or village, or by any corporate authorities, commissioners or persons, pursuant to law, which assessment or installment thereof is required by law to be included in the advertisement and notice of application for judgment for state and county taxes, and the description or sub-division of any real estate described in such return, is different from the description or sub-division thereof as described in the town or district col- 
lector's book returned to such county collector, it shall and may be lawful for the county collector to advertise all the real estate delinquent for any such assessment described in such roturn, according to the description thereof, as contained in such return; but such advertisement shall be made at the same time, and shall form part of his advertisement of real estate delinquent for state and county taxes. [See Secs. 1\%8-188.]

SEC. 2. The said real estate, so advertised, may be described in the county collector's delinquent return, according to the description thereof, as contained in such return and advertisement; and like proceedings shall be had to the application for judgment, and the judgment thereon, the sale and issuance of the certificate of the sale thereof, redemption from such sales and issuance of deeds thereon, as may be required by law to be had in regard to lands delinquent for state and county taxes.

SEC. 3. Any incorporated city, town or village, or corporate authorities, commissioners, or persons interested in any such special assessment or installment thereof, may lecome purchaser at any sale, and may designate and appoint some officer or person to attend and bid at such sale on its behalf.

SEC. 4. Whereas many special assessments are now in process of collection, whereby an emergency exists why this act should take effect immediately: therefore, this act shall take effect and be in force from and after its passage.

\section{APPORTIONMENT OF ASSESSIIENTS.}

AN ACT concerning the Apportionment of Special Assessments, payable in Installments.

Section 1. Be it enacted by the People of the State of Illinois represented in the General Assembly: That in all cases where any special assessment, payable in installments, has been, or hereafter shall be, made by any corporate authority for supplying water, or other corporate purpose, and the owner or owners of any lot, block or parcel of land, so assessed, or some of 
them, shall desire to subdivide the same, and to apportion such assessment and the several installments thereof, in such manner that each parcel of such proposed subdivision shall bear its just and equitable proportion thereof, the same may be done in the manner following, to wit: The owner or owners of such lot, block or parcel of land shall present to such corporate authority a petition, setting forth:

1. The descriptive character of the assessment, and the date of the confirmation of the same.

2. The names of the owners.

3. A description of the land proposed to be subdivided, together with the amount of each installment thereon, and the year or years for which the same are due.

4. A plat showing the proposed subdivision.

5. The proposed apportionment of the amount of each installment on each lot or parcel, according to such proposed suijdivision. Such petition shall be acknowledged in the manner provided for the acknowledgment of deeds, and if such corporate authority shall be satisfied therewith; they shall cause to be endorsed upon, or attached to, such petition their approval, by their clerk or secretary, under their corporate seal, and the same, so approved, shall be filed and recorded in the office of the county clerk in which such land shall be situate; and such apportioned assessment shall stand in place of the original assessment, and the same and the several installments thercof shall be deemed duly apportioned, and the several amounts so apportioned shall be liens upon the several parcels charged respectively; and for the purpose of collecting the same, all proceedings shall be had and taken as if said assessment and installments had been made and apportioned in the first instance, according to such apportioned description and amounts, and the respective owners shall be held to have waived any and all objections to such assessment, and the assessment aforesaid: Provided this act shall not apply to any lot, block or parcel of land on which there shall remain due and unpaid any installment. In case assessors are unable to agree as to such apportionment, or any of them are under legal disability, one or more of them may file a petition with the circuit court of the county in which 
such land so assessed is situate, substantially in form as hereinbefore provided; and in such case, such corporate authority, together with all owners or persons interested, not joined as petitioners, and unknown owners, if any, shall be made parties defendant; and all proceedings in relation thereto shall be had as in cases in chancery. The court may hear and determine the case according to the right of the matter. A copy of the record of all the proceedings of the court in the premises, in case of an apportionment duly certified, shall be filed and recorded in the office of such county clerk, and the same shall thereupon, as to the said land embraced therein, the owners thereof, the apportiomment aforesaid, and the collection of the sereral amounts apportioned, hare the same force and effect, at is heretofore provided, as in cases where such corporate anthoritics shall approve of a petition, and file and record the same. 


\section{ORDINANCES}

AN ORDINANCE for the regulation and government of the public park, which, by law, is under the control and government of the South Park Commissioners, and for the appointment of a police force, and defining the powers and duties of the officers thereof.

Wirereas, by an act of the general assembly of the State of Jlinois, entitled an act to provide for the location and maintenance of a park for the towns of South Chicago, Hyde Park and Lake, it is provided as follows, to-wit:

"The said board shall have full and exclusive powers to govern, manage and direct said park; to lay out and regulate the same; to pass ordinanees for the regulation and government thereof; to appoint such engineer's, surveyors, clerks and other officers, including a police force, as may be necessary; to define and prescribe their respective duties and authority; fix the amount of their compensation; and, generally, in regard to said park, they shall possess all the powers and authority now by law conferred upon or possessed by the common council of the city of Chicago, in respect to public squares and places in said city."

Therefore, be it ordained by the South Park Commissioners as follows:

SECTion 1. 'The said park, which is under the management and direction of the South Park Commissioners, shall be, and the same is hereby designated, as the South Park.

SEC. 2. No person shall, without the consent of the superintendent, play at ball, cricket, or any other game or play whatever, in said park.

SEC. 3. No person shall climb or walk upon any wall or fence of said park. 
SEC. 4. Cattle, horses, goats, swine, or other animals, or domestic fowls, shall not be turned into said park, or allowed to run at large therein.

SEC. 5. No dog or bitch, or domestic fowl, belonging to any othicer or employee of said commissioners residing within the limits of said park, shall be permitted to run at large.

SEC. 6. All persons are forbidden to carry fire arms, or to throw stones or other missiles within said park. All persons are forbidden to cut, break, or in any way injure or deface the trees. shrubs, plants, turf, or any of the buildings, fences, bridges, or other construction or property within or upon said park.

SEC. \%. No person shall converse with, or in any manner hinder, those engaged in constructing or repairing said park.

SEC. 8. No animal shall be driven or ridden in said park, at a rate of speed exceeding eight miles per hour.

SEc. 9. No vehicle, or horse, or other animal, shall be permitted on the foot walks, the same being assigned exclusively to pedestrians; nor shall any vehicle, or horse or other animal of burden, go or be taken upon any part of said park, except upon the carriage drives and upon such places as are appropriated for carriages at rest.

SEC. 10. No vehicles or animals shall be permitted to stand upon the drive or carriage roads of said park, or of any part thereof, to the obstruction of the way, or the inconvenience of travel; nor shall any person solicit parisengers within said park without consent of the board.

SEc. 11. No person shall, within said park, expose for sale any article or thing. nor shall any hawking or pedtling be allowed therein.

SEC. 12. No omnibus, wagon, cart, dray, truck, or other vehicle for carrying goods, merchandise, manure, or other articles, except such as are engaged in repairing or constructing. said park, shall be allowed to enter the same.

SEC. 13. No language, abusive, insulting, obseene, or calculated to occasion a breach of the peace, shall be permitted in said park, nor shall persons tell fortunes, play at any game of chance, at any table or instrument, be drunk, or do any indecent acts therein. 
SEC. 14. No person shall bathe or fish, or go or send, or ride any animals into the waters of said park, nor shall any person disturb any fish, fowl or other animals kept therein, or throw or place any article or thing into the waters or upon the grounds thereof.

SEC. 15. No person shall discharge, or set, or touch off, or enkindle, or operate any manner of fire, or fireworks in the said park.

SEC. 16. No person shall, in the said park, post or fix any notice or bill; wor shall such be posted or fixed on any tree, fence, or any place therein.

SEc. 1\%. No person shall, in the said park, play any musical instrument, nor carry or display any flag; banners, transparencies, or target.

Sic. 18. No band or company shall be permitted to parade, drill, or perform any movements, evolutions or ceremony in said park without the consent of the park commissioners.

SEC. 19. No funeral procession, or hearse carrying a deceased body, shall be in the said park permitted.

SEC. 20. No horse or other animal shall be permitted to go upon any grass or lawn, nor shall any person be permitted to go thereon except where the word "common" shall be posted to indicate the permission so to do.

SEC. 21. Any member of the South Park police shall have power to arrest, and commit for examination, any person who shall not, when directed, desist from any violation thereof.

SEc. 22. Any person who shall disobey, or neglect, fail, or refuse to comply with this ordinance, or any section thereof, except when otherwise herein provided, shall, on conviction thereof, pay a fine of not less than five, or more than one hundred dollars.

SEC. 23. The police force of said South Park Commissioners, shall consist of one captain, three sergeants, and such number of policemen, as shall from time to time be appointed, and they shall hold their respective offices during the pleasure of the park commissioners. The captain of police shall have the general charge of the police force, subject to such rules and regulations as shall from time to time, be established, and it 
shall be his duty to report to the commissioners, in writing, the delinquency of any member of the police force, and may suspend any such member, until such delinqueney shall be acted upon by the commissioners.

SEC. 24. The several members of the police force, when on duty, shall devote their time and attention to discharge of the duties of their station according to the ordinance, rules, and regulations and directions of the superintendent, and it shall be their duty, to the best of their ability, to preserve order, peace, and quiet, and to enforce the laws and the ordinances of said commissioners, and they shall not engage in conversation with an employe of the park during working hours, except in the line of duty; they shall have the power to arrest any persons in the park found in the act of violating any law or ordinance, or abetting and aiding in any such violation, and shall take all such persons so arrested, as follows, to wit: when the offense is committed in that portion of the park, situated in the town of Hyde Park, to some justice or magistrate in Hyde Park, when the offense is committed in that portion of the park situated in the town of Lake, to some justice or magistrate in said town of Lake, and when the offense is committed in that portion of the park situated in the town of South Chicago, to some justice of the peace in said town of South Chicago.

SEC. 25. Whoever, in said park, shall resist any member of the police force in the discharge of his duty, or shall in any way interfere with, or hinder or prevent him from discharging his duty, as such member, or shall offer or endeavor to do so; and whoever shall in any manner assist any person in custody of any member of the police force, to escape, or attempt to escape, from such custody, or shall rescue, or attempt to rescue, any person in custody, shall be fined not less than five dollars, or more than one hundred dollars.

SEc. 26. 'The superintendent, in eases of emergeney, is hereby' authorized and empowerer to appoint special policemen, and such special policemen shall have the same power and authority of regular policemen, provided the appointment of such special policemen shall in no case continue for a period exceeding twenty-four hours. 
SEC. 2\%. The sergeant of police shall perform the duties of the captain when the latier shall be absent from duty.

SEC. 28. The police force shall be uniformed as follows: Grey frock coat, pants and vest, and cap with brass buttons, and black cord on leg of the pants.

SEc. 29. Any person who shall falsely represent or personate any of the members of the police force, or who shall maliciously: with intent to deceive, use or imitate any of the signs, signals, or derices adopted and used by the police department, or shall wear in public the uniform adopted as the police uniform, after having been removed or suspended, shall be subject to a fine of not less than five dollars nor more than one hundred.

SEC. 30. These ordinances shall take effect and be in force from and after the 19th day of November, $18 \% 5$.

\section{JuRISDICTION OF JUSTICES.}

SEC. 14. "Justices of the Peace shall have jurisdiction in "all cases for violation of the ordinances of cities, towns, or "villages." [R. S. 18\%4, 639.]

Justices of the Peace and Police Magistrates have jurisdiction to enforce the foregoing ordinances, as the Park Commissioners are the corporate authorities of towns for park purposes. 'The act which provided for their appointment, sec. 13, is as follows:

"SEC. 13. The said board shall have the full and exclusive power to govern, manage and direct said park; to lay out and regulate the same; to pass ordinances for the regulation and government thereof; to appoint such engineers, surveyors, clerks and other officers, including a police force, as may be necessary; to define and prescribe their respective duties and authority; fix the amount of their compensation; and generally, in regard to said park, they shall possess all the power and authority now by law conferred upon, or possessed by the common council of the city of Chicago, in respect to the public squares and places in said city; and it shall be lawful for them to commence the improvement of said park as soon as they have obtained one hunrled acres of the premises herein described." 
See also case of People ex rel. Witson r. Salomon, supra, by which it is decisled that the commisisoners ane corporate authorities of towns for park purposes, as set forth in the Park Act, sec. 13 of which, as above quoted, gives them the same power that is enjoyed by the Common Council of Chicago over the parks in Chicago. By the charter of ('hicago, the common council is authorized to pass and enforce ordinances for the government and protection of all parks in the city, within the control of the city government. 


\section{HISTORICAL}

The South Park Act was approved Feb. 24th, 1869, and the act amendatory and supplementary thereto was approved April 16th, 1869; whereupon, on the sixteenth day of April, A. D. 1869, John M. Wilson, George W. Gage, Chauncey T. Bowen, L. B. Sidway and Paul Cornell, having been duly appointed commissioner's, qualified as such; and on the thirtieth day of April, 1869, organized as a board, by the election of John MI. Wilson as president, l'aul Cornell, secretary, George IT. Smith. treasurer, and George W. Gage, auditor.

Chauncey 'T. Bowen's term of office having expired on the first of March, 18\%0, he was re-appointed, and afterwards, on the first day of February, 18\%1, he having resigned, the vacancy was filled by the appointment of Potter Palmer. George II. Gage's term having expired on the 1st of March, 18\%1, he was reappointed. Paul Cornell's term having expired on the first of March, 1872, he was re-appointed. On the 2nd of May, 1872, Hon. Jno. M. Wilson resigned, and C. T. Bowen was appointed to fill his place, and in March, 1873, the time for which he was appointed haring expired, he was re-appointed to serve for five years. L. B. Sidway's term expiring in Narch, 18\%4, he was re-appointed for five years. In April, 18\%4, Potter Palmer resigned, and James Morgan was appointed in his place.

Mr. Cornell resigned the office of secretary on the first day of March, 18:1, and William L. (ireenleaf was appointed to fill the vacancy. On the 19 th of March, 1873, W. I. Greenleaf was appointed collector of the board, and H. W. Harmon was elected secretary. George W. Smith resigned the office of treasurer on 
the first day of December, 18\%0, and J. Irving Pierce was elected to fill the vacancy. Mr. P'ierce's term of office having expired, Isaac N. Hardin was elected treasurer on the 13th day of March, A. D. 18\%1. On the expiration of his term, in Mareh, 1872, J. Irving Pierce was elected his successor. George W. Gage continued to hold the office of auditor until the 13th day of March, 18\%1, when he resigned, and L. B. Sidway was chosen to fill the vacancy. Mr. Sidway held the office of auditor until Marel, 1875, when George W. Gage was again elected auditor, and served until his death, on the 2tth Sept., 18\%5. The board, as at present organized, consists of Chauncey T. Bowen, president, L. B. Sidway, auditor, Paul Cornell, James Morgan, with a vacancy in the board yet to be filled by the circuit judge.

Soon after the organization of the board in 1869, and within the time limited by the act establishing the South Park, the lands designated in said act were formally selected by the commissioners, and an accurate description of the same placed upon their records. Immediately thereafter, the board examined the said lands and made diligent inquiry in relation to their value. The probable cost of the lands was estimated at $\$ 1,865,750$, and an application was made to the circuit court for the appointment of three assessors to assess that amount upon the property benefited. This application having been refused, the board applied for a mandamus to the Supreme Court. 'The case made was argued before the Supreme Court, and a mandamus awarded. Thereupon the circuit court appointed assessors, who entered immediately upon the performance of their duties. It was afterwards ascertained that the cost of the lands composing the park would considerably exceed the original estimate; and the board, having been authorized by the act of June 16th, 18\%1, to revise, enlarge and correct the estimate which had been made, it was decided, upon further examination and inquiry, to increase the assessment to $\$ 3,320,000$.

The board, during their administration, have succeeded in purchasing the larger portion of the lands; the part not yet procured being about 100 acres in the East division of the park, the frontage from State street to Wabash avenue on the South side of Pavilion Boulevard, and a portion of the Western avenue 
frontage. The board have acquired title to, and paid for the following amount of lands:

Acres.

East Division of Park ................ 295

Midway Plaisance .................. 60

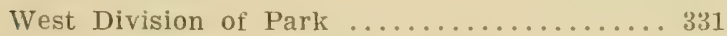

Grove Parkway (11/2 miles front)......... 22

Grand Boulevard ( 2 miles iong).......... 24

Pavilion Boulevard ( $31 / 2$ miles long)....... 42

Twenty Acre Fark ................ 6

780

They have also acquired title to, partially paid for, and assumed liabilities on, the following amount:

Acres.

East Division of Park .............. 200

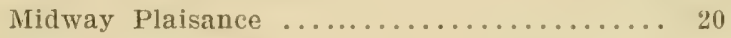

West Division of Park ............... 28

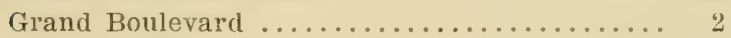

Twenty Acre Park ..................... 3

Western Avenue (frontage $3 / 4$ mile)....... 12

265

At this date, the abstracts are being examined for about onehalf mile more of frontage on Western avenue, preparatory to purchase, leaving alout one and one-ruarter miles of frontage on Western arenue still to be acquired. The board hope, by Spring, to procure the Western avenue lands, and lay them out, and improve them to some extent, as the property holders of that section express themselves very favorably to the project, and seem willing to further the wishes of the commission. In addition to the boulevard, the board propose to make a twentyacre park at the junction of Pavilion Boulevard and Western avenue, and a portion of the land has already been procured. The failure of the commiswion to collect the delinquent portion of the park tax, has been of great detriment to them in their labors, as the money, if collected, would have gone directly to the improvement of the grounds, and the work on the park would have been forwarded proportionally faster, to say nothing of the expense incurred for interest on temporary loans, \&c. It 
is a matter of regreet to the hoard that the law affords no present means of hastening the collection of the delinquent taxes.

After the fire of $18 \% 1$, the board were of the opinion that the Park tax, if called for to the greatest extent of the law, would be burdensome to tax payers, and that it would be considered unjust to ask for an appropriation for purposes of recreation, when the necessities of the community called for so large an expenditure. The board therefore concluded to make the tax for an amount simply sufficient to cover their interest, namely: $\$ 150,000$.

As it since appears, it was unwise, for the business of the following year was inprecedentedly good, and time has prored that the taxes of that year were paid more cheerfully than at any time since. The result was a loss of, at least $\$ 100,000$, to the Commission.

Note.-The delinquent taxes for the previous years are as follows:

Total tax levy $1870 \ldots \ldots \ldots \ldots \ldots \ldots \ldots \ldots \ldots \ldots \ldots \ldots, 200.62$

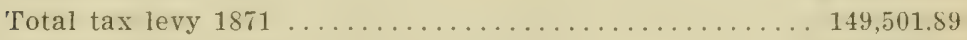

Total tax levy 1872 ....................... 299,535.25

Per tax 1869, double payments, interest on forfeitures, etc. 516.80

$\$ 748,754.53$

Commissions paid, $1870 \ldots \ldots \ldots \ldots \ldots \ldots \ldots 13,757.87$

Commissions paid, $1871 \ldots \ldots \ldots \ldots \ldots \ldots \ldots$ 2,537.23

Commissions paid, $1872 \ldots \ldots \ldots \ldots \ldots \ldots \ldots \quad 3,984.54 \$ 20,279.64$

Cash received on 3 year Warrants......... 637,178.76

Errors and abatements, $1870 \ldots \ldots \ldots \ldots \ldots . \ldots 22,999.58$

Errors and abatements, $1871 \ldots \ldots \ldots \ldots \ldots 22,703.26$

Errors and abatements, $1872 \ldots \ldots \ldots \ldots \ldots \ldots$. 45,593.29

$91,296.13$

$\$ 748,754.53$

It will be seen by this, that the delinquent taxes for the three years amount to over one-eighth of the total levy; adding commissions paid to town and county collector's, the actual deficit is nearly fifteen per cent. of the amount allowed by law. In addition to this, is the amount delinquent for 1869 , amounting to nearly $\$ 40,000$, which is wholly lost; the fire of $18 \% 1$ having wiped it out. The total tax levy for $18 \% 3$ is about $\$ 302,000$, of which there is no report to date, but as nearly as can be esti- 
mated, will be delinquent about $\$ 55,000$. It is hoped that a number of these old cases will be reached at the coming term of court.

In the East Division of the park the Commission have met their greatest difficulty in gaining a title sufficient to warrant their proceeding in the work of improvement. The rery finct that the surface of the ground admits of no other way of laying out, except in continuous lakes and lagoons, as planned by Olmstead \& Vaux, in their original draught of the park, prevents them from beginning the work without the possession of the whole tract. The board, at the present time, are endeavoring to further the condemnation proceedings in sections 13 and 24 , and when once the title to the land is secure, the work of improvement can be pushed forward much faster than elsewhere, from the natural advantages of the ground, and its fine growth of timber.

Nearly four-fifths of the West Division of the park is completed, as far as the labor is concerned. About 350 acres have been tilled and seeded down, and planted with forest trees, of from 3 inches to 12 inches in diameter. The portion known as the "South Open Green," is now laid out as a lawn, and it is probably the most extensive one in America.

The Commission have built and completed the four main boulevards, viz., Grand Boulevard, Drexel Boulevard, Parilion Boulevard, and Oakwond Boulevard, with a complete and perfect system of sewerage, in all, 111/2 miles of road.

They have furnished the connecting drive between the East and West divisions of the park, one mile in length, and 40 feet in width.

They have also completer the Northem drive in the East park, three-fourths of a mile long, and 40 feet wide, running from the Nidway Plaisane to the lake shore: through the parks themselves, some $31 / 2$ miles of drive have been completed; about three-fourths with Joliet gravel, and the remainder with clay and lake shore gravel. About six and one-half miles of walks, of clay and lake shore gravel, have been finished.

The boulevards have all been planted with large forest trees, and five years ago, the Commission established a nursery in the 
West park, in which such young trees and shrubs as were considered desirable for park purposes, were planted. This nursery has been a complete and perfect success, and now furnishes several thousand first class trees each season, which are planted in their proper places on the parks, their places in the nursery being filled with young stock, that in two or three years is ready for park planting. By this means the park will eventually all be planted with thoroughly acclimated trees of the best quality, at the lowest possible cost.

The floral department and botanical garden, are well established, with good hot-houses, steam forcing apparatus, \&c. The board are now enabled to furnish themselves all their own plants for these walks and drives. The general plan of the Commission for constructing and improving the park, was to begin at a point nearest the largest population, and make all improvements continuous to the farthest point. And they have made no improvement at any point that could not be reached from the eity over park roads.

The many difficulties connected with the obtaining of the land for park purposes, resulting from the exorbitant prices demanded by property owners as soon as the park bill entered into effect, and the vexatious delays consequent from the slow process of law where the parties interested could not agree, have hindered to a great extent, the Commission in their improvements, and the difficulty of procuring the payment of taxes and assessment promptly, has caused them much regret that their regular improvement could not progers as fast as they themselves would have desired. But they have at last succeeded in getting a park with its attendant drives, and time will have to complete in the growth of its trees and shrubbery, what they have at last succeeded in starting. 


\section{IN MEMORIAM}

Geo. W. Guge was appointed South Park Commissioner on the 16th day of April, 1869. On the organization of the Board on the 30th of April, 1869, he was chosen auditor, and served to the expiration of his term, which expired on the 1st of March, $18 \% 1$.

On the first of March, 18\%1, he was reappointed, to serve for five years. He resigned as auditor on the 13th day of March, $18 \% 1$.

He was again elected auditor on the 6th day of March, 1875, which oftice he filled until his death on the 24th day of September, 1875 .

During his whole time of service in the South Park Commissioners, he served as chairman of the construction committee. The roadways and boulevards of the park, and their attendant system of sewerage, stand as monuments of his ability and energy.

The following resulutions were arlopted by the Board of South Park Commissioners, on the 25th day of September, 18\%5:

Whereas, It has pleased Divine Providence to remove from our midst one of the members of the South Park Commissioners, Geo. W. Gage, late Auditor of the Park Board; and

Whereas, Mr. Gage has been ever since the organization of the Board in 1869, an energetic, thorough and intelligent member of the Commission, ever having the interests of the public at heart, firm to all, forgetting the rights of none, and a faithful, honest and efficient officer; therefore

Resolved, That the Secretary be, and he is hereby instructed 
to close the office of the South Park Commission for this day, out of respect to his memory. And further

Resolved, That the Commissioners hereby tender to the friends of the dereased their heartfelt srmpathy in their berearement, assuring them, as well as the putblic. that during the six years of his official life as Park Commissioner, he has ever had the interests of the public at lieart, while his julgment and experjence were ever found of great henefit to the Commission associated with him.

Resolved, That the Secretary be, and he in hereby directed to send to the family of the deceased a copy of these resolutions, and to spread the same on the records of the Commission. 


\section{OPINION OF THE SUPREME COURT OF ILLINOIS,}

Northern Grand Division,

IN A CAUSE SLBMITTED AT TIE SEPTEMHER TERA THEREOF. $18 \%$.

No. $2 \% 8$.

THE PEOPLE, EX REL.

HENRY B. MHLLER, ETC.,

vs.

P. H. BRISLIN, ET AL.
Appeal from C'ounty ('ourt of Cook County.

Filed Jan. 21st, $18 \% 6$.

\section{Opinion by Sidney Breese, Justice.}

This is an appeal from the County Court of Cook County, prosecuted on behalf of the People of the State, in the name of Henry B. Miller, exercising the powers, and performing the duties of county treasurer of Cook County, and ex officio collector of the same; and several grave questions are raised on the record.

It appears the relator, Miller, as county treasurer of Cook County, applied to the County Court for judgment for the third installment of a special assessment made by the South Park Commissioners, pursuant to an act of the General Assembly of this State, entitled "An act to enable the corporate authorities "of two or more towns, for park purposes, to issue bonds in re"newal of bonds heretofore issued by them, and to provide for" "the payment of the same; to make, raise, and collect a special "assessment on contiguous property for benefits by reason of "the location of parks and boulevards, and to make necessary "changes in their location," in force July 1, 18\%1. This is a public law, applicable to every county in the State, and is not amendatory of any other act. (R. S. 18\%, Ch. 105.) Prior legislation had made provision for the location and maintenance 
of a public park for the towns of South Chicago, Hyde Park and Lake (Sess. Laws 1869, 1 Vol., 358), which was amended and supplemented by an act passed 16th April of the same year. (Ib., 366.) The first mentioned act was submitted to a rote of the people of these torns, and it was accepted by them, by majorities in each of the towns. By it, the location of the park was fixed, and its limits defined. The subsequent act made some inconsiderable changes in the first act, and made more definite the dereription of the park, and legalized and entirmed the acts therefor.

Pursuant to the provisions of these acts, park commissioners were appointed by the Governor, who entered upon the dircharge of their duties. Soon thereafter, a question as to their powers and duties was raised in this Court, and settled by its adjudication.

The Pleople ex relatione Wilson v. Salomon, 51 Ill., $3 \%$.

This case holds that under the first named act the towns of South Chicago, Hyde Park and Lake were erected into a park district, and the people of those towns, having by vote accepted its provisions, the board of park commissioners thereby created became a quasi municipal corporation, in whom it was competent for the legislature to vest the power to assess and collect taxes, within the park district so created, for the special corporate purpose of the creation of a park. Accordingly, it was held, it was the duty of the county clerk of Cook County to place the amount required for such purpose, as estimated by these commissioners in the tax warrants for the towns embraced in the district. Estimates have been made by the commissioners from time to time, lands purchased, and bonds issued the refor, and the money raised by their sale cxpended in completing the park. To aid the commissioners to advance the work, the act first above cited, in force July 1, 18\%1, was passed, and in pursuance of its provisions, the commisioner's mark an estimate of the probable cost of lands taken, and to be taken for the park, together with the expenses of obtaining them, and the cost of making and collecting a special assessment to pay the cost of these lands, and the expenses attending their acquisition. The aggregate was estimated at three millions, three hundred and twenty thousant dollars. 
By the first section of the act of $18 \% 1$, the park commissioners are declared to be corporate authorities of the towns which have united in the establishment of a park, and are authorized to discharge the duties imposed upon them as a corporation or otherwise. By section 3 power is given to these corporate anthorities to make the improvements, establish and maintain them by special assessment or special taxation of contiguous property, and they are required to apportion the estimates upon the lands situated in those towns which the corporate authorities may deem benefited by reason of this local improvement, as near as may be, in proportion to the benefits resulting thereto. Ten days' notice to parties interested to be given by the corporate authorities, in one or more newspapers, of the time and place of the meeting to make the assessment, when they can be heard touching any matter comnected with the assessment.

The same section gives a rule to guide the authorities in making the assessment, and when completed, it is to be signed by these authorities, or by a majority of them, and returned to the Circuit Court of the county in which such towns are situated, and filed with the clerk of that court, of which ten days' notice is to be given by the authorities, and the further notice that they will apply on a day named to the Circuit Court for a confirmation of the assessment. The requisites of this notice are given in the section.

It is further provided, when it shall appear to the court that proper notice has been given, it shall have power to hear, adjudge, and determine the matter of said application, and all matters connected therewith.

The corporate authorities, observing all the requisites of this act, made their assessment roll, which was duly reported to the Circuit Court of Cook County, and filed with the clerk thereof, and at the June term, 18\%2, of said court, an order of confirmation of the assessment was duly entered by the court, the court finding that all the preliminary steps had been taken by the corporate authorities, and that the assessment was made in proportion as near as may be, to the benefits resulting from the improvement to each separate lot, block, or parcel of land mentioned in the assessment roll. And the court further found 
that all and every of the proceedings of the commissioners in the premises, were regular, valid, and in conformity with law, and that they have done all things required of them by law, to make this special assessment a legal, just, valid, and binding assessment, in whole and every part thereof, and that the same and every part thereof, was a just and fair assessment in the premises.

It was therefore ordered, adjudged, and determined, by the court, that the assessment, and every part thereof, as set forth in the assessment roll filed herein be, and the same was in all respects confirmed, and should be taken to stand gond and ralicl, and effective, to all intents and purposes, according to the form and meanings thereof, as made and returned to the court by the South Park Commissioners, and certified by them.

The court further, in pursuance of this same section, divided the assessment into annual installments, and fixing the first installment, and dividing the residue of the assuswent into seren equal installments, bearing interest at the rate of seven per centum per annum.

These installments were ordered by the court to be extended separately, under each successive year on the assessment roll, in such a manner as to show the separate amount chargeable upon the several lots, blocks, and parcels of land contained in the tabulated statement in the assessment roll, the court reserving all further matters relating to the division into installments, and the extensions thereof into and upon the assessment roll, until the same shall be ostensibly carried out and extended agreeahly to the order of the court, of which all parties entitled to be heard were required to take notice.

The court having apportioned the gross amount of the estimate, the park commiscioners made a tabulated statement thereof, showing the amount chargeable on each lot, lolock, and parcel of land, acerding to this apportionment and iustallments, and reported the same to the Circuit Court at the August term, $18 \% 2$, whereupon the court entered an order confirming in all respects the apportionments of the assessment by the commissioners, ordering that the division into eight installments, and the estimations thereof as shown upon the assessment roll and 
tabulated statement, be in all respects ratified, approved, and confirmed, and the same be held and taken as good, valid, and effectual, to all intents and purposes. By the same section (3), the clerk of the court was required to deliver to the corporate authorities a certified copy of such assessment, so confirmed by the court, which is declared to be their authority to collect the same.

It is also provided in this section, if the assessments, or any part thereof, so confirmed, shall not be paid at the time or times fixed by the Circuit Court, it shall be the duty of the corporate authorities to return to the county treasurer, or to some general officer of the county having authority to receive State and county taxes, a list of the lots, blocks, and parcels of land so assessed, upon which the assessment should remain unpaid, and the amount unpaid upon each lot, block, and parcel of land.

Appellee and others being delinquent in payment of the third installment of the assessment, the park commissioners made a return of the delinquent list to the county treasurer, and by law ex officio county collector, of the amount due and unpaid of this installment of the assessment, and he, having altered the cescriptions in the return to conform to the descriptions given in the tax book for the State and county taxes, as authorized by the act of May 2, 1873, entitled "An act in relation to the col"lection of taxes and special assessments," he duly advertised the delinquent real estate assessed, that he would apply for judgment to the Cook County Court.

It is to the objections made in that court to the rendition of a judgment against the lots and real estate of appellees, our attention is called. 'They are fifty in number, some going to the form of the proceedings, and others to the merits.

The court refused the application for judgment, and the People appeal. The merits of the controversy are presented in the points argued by appellee in this Court, and are involved in objection numbered forty-eight, which is as follows:

"Because the act entitled 'An act to enable the corporate "authorities of two or more towns, for park purposes, to issue "bonds,' etc.; approved June 16, 18\%1, under and by virtue of 
"which said assessment was levied and confirmed, is void and "unconstitutional, for the reason that the same has never re"ceived the assent or approval of the legal voters of said towns "intended to be affected thereby; and for the reason that it au"thorizes the issue of a new and unlimited amount of bonds, "bearing interest at seren per cent., payable annually, for the "payment of which, both principal and interest, the lands and "lots of the objectors are bound; and for the further reason that "it authorizes interested parties to lery assessments upon lots "and lands in said town; and for the reason that it authorizes "the Circuit Court to confirm and establish the assessment when "made, without personal notice to the parties interested; and for "the reason that it imposes heavy burdens upon the property "owners and legal voters of said towns, to which they have "never in any manner assented; and for the reason that said act "is repugnant to the terms of the constitution; and all proceed"ings under the same are null and void."

We have given to the objections, and the argument in their support, as much consideration as possible, and can not think they are tenable.

The first clause of the objections to the act of 18\%1, enlarging, so to speak, the powers of the corporation of park commissioners, that the same has not been submitted to a vote of the people of the towns composing the park district, and receired the approval of the voters thereof, has in some respects, been considered by this Court, in Bank of the Republic v. Hamilton County, 21 Ill., 53.

The fifteenth proposition for discussion in that case, was this: whether the said amendatory act of $185 \%$, in imposing additional burthens upon the banks, without any corresponding advantage or benefit conferred, and not authorized at the time of the passage of the general banking laws, in its adoption by the people, is not wholly null and void, and in conflict with the Constitution of the United States, as impairing the obligations of contracts.

To understand the force and bearing of this proposition, it will be rememberer that clause 5 of Article 10 of the Constitution of 1848, title, "Corporations," has this provision: "No act 
"of the General Assembly, authorizing corporations or associa"tions with banking powers, shall go into effect, or in any man"ner be in force, unless the same shall be submitted at the gen"eral election next preceding the passage of the same; and be "approred by a majority of all the rotes cast at said election, "for and against such law."

The General Assembly, at the session of 1851, passed an act to establish a general system of banking, containing forty-one sections. Section 39 thereof provided for the submission of the act to a vote of the people at the general election to be held on the 'Tuesday next after' the first Monday of November, 1851, and providing if the same be approved by a majority of all the rotes cast at the election for and against the same, it should go into effect, and be in force from and after the date of the election. (Sess. Laws 1851, p. 163.)

The act was approved by a rote of the people at that election, and thereupon became a law. This law contained all the provisions then deemed necessary to the establishment of a proper banking system.

At the next session held in 1853, an act was. passed, supplemental to, and explanatory of this act, by which important changes were made, and in $185 \%$, other important changes were made in the law, giving rise to the ease then in judgment. 'This act is entitled: "An act to amend 'an act to establish a general "system of banking, and the acts amendatory thereof." (Sess. Laws 185\%, p. 23.)

The sixth section of this law made a great change in the mode of ascertaining the value of the property of the banks, on which it was to be assessed, from that provided by the tenth section of the general banking law, under which the appellant bank was organized.

It was contended in that ease, that this change was void under the clause of the constitution we have cited, it not having been submitted to a vote of the people for their approval, and that it was a violation of their chartered rights.

These questions were duly considered, and this Court said: While we must be unyielding in resistance to encroachments "pon chartered rights which may be in the nature of contracts, 
we must not forget that these artificial beings must be subject to government, and be subordinate to legislation, precisely the same as an individual or natural person.

On the question that the act was invalid, because it was not submitted to the people, the court had no doubt of its validity, and it was so determined. We think the reasoning and conclusions reached in this case dispose of so much of objection fortyeight.

There is, certainly, force in the argument of appellee, that, as the legislature had not of itself the power to ereate "corporate "authorities," without a vote of the people, then if that vote was obtained subject to certain limitations and conditions, those limitations and conditions must be olsecred by, and are binding upon, both the legislature and the corporate authorities.

This was the kind of argument used in the case of The Bant of the Republic, supra, on which we have commented.

The park district, when established in pursuance of the act creating it, became a municipality for certain purposes, and as such came within the domain of legislation. The powers of the corporate authorities of this municipality are subservient to the legislative power, precisely as in the case of other muncipalities, and are not interfered with by the present State Constitution; on the contrary, their existence is implied by the terms of section 9 of Article 9, giving them powers to make special assessments for local improvements, or by taxation of contiguous property, or otherwise.

This act of $18 \% 1$ in no degree trenches upon this article, but is in conformity therewith.

The argument seems to go to this extent, that the Legislature cannot enlarge, and if they cannot enlarge, cannot curtail the powers of public corporations. In all clse, save interfering with such rights as may belong to the domain of contracts, the legislature is supposed to have plenary powers.

Should a city, by a popular vote, adopt the act of $18 \% 2$ for the incorporation of cities and villages, that act would, eo instanti, become the charter of the city or village adopting it. It will hardly be contender that amendments to this act not invading the contract rights of the city or village, will be invalid and 
nugatory, if not submitted to a rote of the people. We think it is a fair deduction from all the constitutional provisions, and from the very nature of our government, that changes determined by the exigeney of the times in regard to municipal corporations are within the domain of ordinary legislation.

As to the point that these commissioners were never authorized by the people of these towns to levy a tax of more than three hundred thousand dollars, it will be observed that amount ean be levied annually. That sum is not the ne plus ultra. They have power to assess a sufficient amount to carry on the enterprise, and if only $\$ 300,000$ are called for annually, no matter what the ultimate expenditure may be, such a call is legitimate, and that amount can be ammually assessed, and it is so assessed by the action of the Circuit Court, dividing the gross assessment into eight anmual installments. It is clear the object of all this legislation, from 1869 to June $16,18 \% 1$, was to provide a public park, and it was intended by the legislature to construct proper machinery for such purpose. True, the legislation to effectuate this intent must not contravene the constitution. To say this act of $18 \% 1$ contravenes clause 13 of Article 4, providing that no act hereafter passed shall embrace more than one subject, and that shall be expressed in the title, is going very far. What was the subject of this legislation? A public park, and its then existing concomitants. Land for the park was to be acquired-contracts made therefor-bonds issued for the cost and expenses-assessments to pay existing and future liabilities-these were the concomitants which the legislature had in view, in passing the act of 18\%1, with the title it bears, and we cannot see that it is obnoxious to any objection. This Court has gone very far to uphold statutes supposed to have been within this objection. The case of O'Leary v. Cook County, $28 \mathrm{Ill} ., 534$, is a conspicuous instance. The body of the act in question is germane to the title of the bill.

But the point is pressed, that this assessment is not on contiguous property. 'This question, and all others, bringing up the levy and assessment, have been passed upon by the Circuit Court, and are res judicala, and cannot now be made in this Court. Upon them there is a judgment pronounced by a court of com- 
petent jurisdiction, and there they must rest. The fact that the commissioners who made the estimates and assessments were property owners in the towns, could not disqualify them. They were made by the law the tribunal for the purpose, and were required to take an oath faithfully and impartially to discharge their duties for the public interest. We are of opinion they were not disqualified-the law appointing them qualified them.

The objection made by appellee, that two judgments have been rendered against the same lands in the same proceeding, is not clearly understood. In this case, there was no judgment rendered for these assessments, and that is the cause of complaint here made by the party claiming the judgment. Appellee has net assigned any cross errors, and we do not see how this objection can be made.

A further objection is made, that the county treasurer as collector had no power to act in this matter, and to apply for judgment, as the County of Cook is not under township orgmization. Not being so, the sheriff of the county is ex officio the collector, and the application for judgment should have been made by him.

That Cook County is under township organization, reference is made to clauses 6 and $\%$, of Article 10 of the Constitution.

By a fair implication from the language used in these sections, the County of Cook is not taken out of the class of counties muler township organization, that being the condition of the county before the adoption of the Constitution. And this is strengthened by reference to section 23, Ch. 34, title "Counties." So much of that section as is applicable, is as follows:

"The powers of the county as a body corporate or politic shall "be exercised by a county board, to wit: In counties under "township organization (except the county of Cook), by a board "of supervisors, \&c., in the county of Cook, by a board of county "commissioners, \&c., in counties not under township organiza"tion, by the board of county commissioners." (Page 306.) And also by clause 11, of Article 11, of Chap. 139, title "Town"ship Organization." "The supervisors of towns in Cook County "shall perform the same duties as supervisors of towns in other "counties under township organization, except that they shall 
"not be members of the county board, or exercise any of the "powers thereof." (Page 1080.) We think it a fair inference from all these provisions, that the county of Cook must be considered as under township organization, and consequently the treasurer of the county was the proper person to make this application for judgment.

After a careful examination of this record, and full consideration of the points raised upon it, we find no ground justifying the county court in refusing jurlgment on the application of the county treasurer for judgment. He had ample power by section 178 of the Revenue Laws.

The judgment of the County Court is reversed, and the canse remanded to that court, with directions to enter judgment, notwithstanding the objections.

I, Cairo D. Trimble, Clerk of the Supreme Court, in and for the Northern Grand Division of the State of Illinois, do hereby certify that the foregoing is a true copy of the final opinion of the said Supreme Court in the above entitled cause, of record in my office.

In testimony whereof, I have set my hand, and affixed the seal of the said Supreme Court, at Ottawa, this 22d day of January, in the year of our Lord one thousand eight hundred and seventy-six.

C. D. TRLIBLE,

[SEAL.]

Clerk of the Supreme Court. 



\title{
OPINION OF THE SUPREME COURT OF ILLINOIS,
}

\author{
Nortitern Grand Division,
}

IN A CAUSE SUBMITTED AT THE SEPTEMIBER TERM TIIEREOF, 1875.

No. 254.

FRANCIS B. LAIV

vs.

THE PEOPLE, EX REL.

HENRY B. MILLER, ETC.
Appeal from County Court of Cook County.

Filed Jan. 21st, $18 \% 6$.

\section{Opinion by John M. Scott, Chief Justice.}

This appeal is from a judgment on a special assessment for park purposes. Under the reasoning in The People ex rel. $\nabla$. Bustin et al., decided at the present term, the assessment and judgment are valid, and we will not discuss the questions raised further in this opinion.

The description of the property given is sufficiently accurate and definite for all the purposes of the assessment. According to the doctrine of Colcord v. Alexander, 67 Illinois, 581, any description adopted in a deed by which the premises intended to be conveyed may be established and identified is sufficient, and a grant, or devise, will only be declared void for uncertainty, when, after resort to oral proof, it still remains a matter of mere conjecture what was intended by the instrument. It is apprehended the sale may be less stringent, as to description of property for taxation, than in a grant, or conveyance, intended to pass the title absolutely. Any description by which the property may be identified by a competent surveror with reasonable certainty, either with or without the aid of extrinsic evidence, will be sufficient. 
In this case, we think any competent surveyor, even from the description given, without any extrinsic aid, could locate and determine what property was assessed, and that, under all the authorities, is sufficient.

Objection is made, that the delinquent list, and the affidavits to the record of the same, are insufficient. We are unable to perceive in what particular there is any defect. According to the decision in Andrews v. The People, ex rel., (Sept. T. 18\%4), the general revenue act of 1872 necessarily worked a repeal of all prior conflicting laws, whether found in the provisions of general laws, or in those of special eity charters. The county collector was, therefore, the proper party to make the affidavit. It is in due form, and is sufficient. The fact the commissioners may have attached their affidavits, also, does not vitiate the return.

The judgment must be affirmed.

Judgment affirmed.

I, Cairo D. Trimble, Clerk of the Supreme Court, in and for the Northern Grand Division of the State of Illinois, do hereby certify, that the foregoing is a true copy of the final opinion of the said Supreme Court in the above entitled cause, of record in my office.

In testimony whereof, I have set my hand and affixed the seal of the said Supreme Court, at Ottawa, this 24th day of January, in the year of our Lord one thousand cight hundred and seventysix.

[SEAL.]

C. D. TRIMBLE, Clert of the Supreme Court. 



$$
\text { H } 27484
$$





र

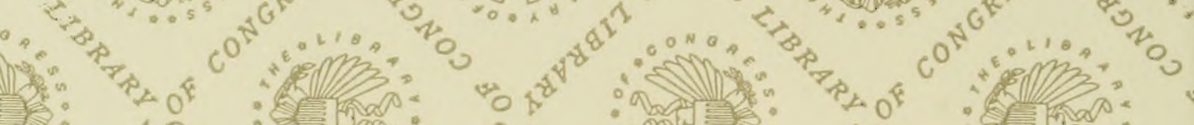

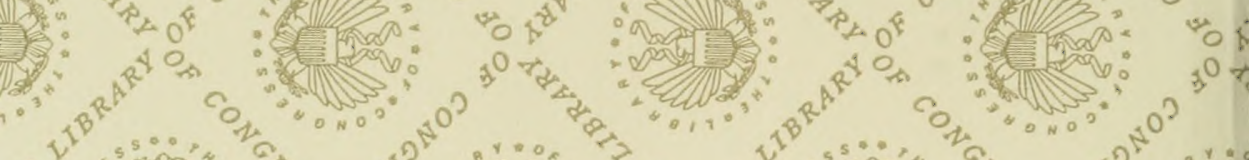
(4) $\Rightarrow$ "

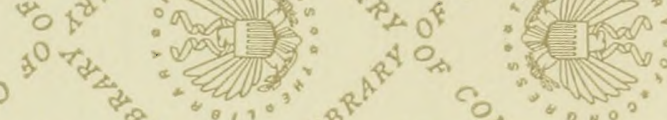

15:

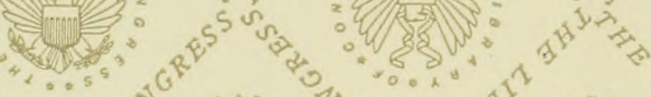

Pat

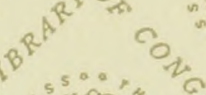

Rent: "

कर

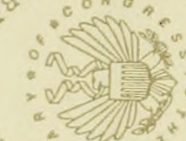

00

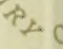




\section{LIBRARY OF CONGRESS \\ ||||||||||||||||||||||||||||||||||||||||||||||||||| 0000911, ? ? 4}

